\title{
EL LINAJE AVENDAÑO: \\ CAUSAS Y CONSECUENCIAS DE SU ASCENSO SOCIAL EN LA BAJA EDAD MEDIA
}

\author{
THE AVENDAÑO LINEAGE: \\ REASONS AND CONSEQUENCES OF ITS SOCIAL RISE \\ DURING THE LATE MIDDLE AGES
}

\section{ERNESTO GARCÍA FERNÁNDEZ Universidad del País Vasco}

Resumen: Los Parientes Mayores de la Casa de Urquizu, cabeza del bando gamboíno en Vizcaya, se constituyeron en uno de los principales linajes solariegos del País Vasco durante la Baja Edad Media. En este artículo se examinan la evolución genealógica, los entramados de parentesco y las relaciones sociales de un linaje que cimentó su ascenso político en su lealtad hacia los Señores de Vizcaya y los Reyes de la Corona de Castilla. Su implicación en las luchas sociales y políticas del Señorío de Vizcaya fue una consecuencia del poderío alcanzado en el Nordeste de la Corona de Castilla durante los siglos XIV y XV.

Palabras clave: Nobleza; Caballería; Linaje; Edad Media; País Vasco; Corona de Castilla; Biografía social; Pariente Mayor; Lucha de Bandos; conflicto social; Vizcaya; Guipúzcoa; Álava; Prosopografía nobiliaria.
Abstract: The Parientes Mayores, or heirs of the Casa de Urquizu, head of the gamboino faction in Bizcay, formed one of the largest lineage of the Basque Country, throughout the Late Middle Ages. This paper analyses the evolution of its genealogy, the family connections and the social relations of a linage that founded its political rise in its loyalty to the Señores de Vizcaya and the Kings of Castile. Its participation in the social and political struggles of the Señorío de Vizcaya was a result of the power attained by the family in the northwest of the Castilian Kingdom, along the 14 th and $15^{\text {th }}$ centuries.

Keywords: Noble families; Knighthood and Chivalry; Lineage; Middle Ages; Basque Country; Castilian Kingdom; Social biography; Parientes Mayores or eldest son and heir; Faction struggles; Social conflict; Bizcay; Guipúzcoa; Álava; Nobiliary prosopography. 
SUMARIO

1. Introducción.- 2. Los presuntos orígenes del linaje.- 3. Un linaje de caballeros al servicio de los Señores de Vizcaya y de los Reyes de Castilla: de Martín Ruiz de Avendaño a Juan de San Juan de Avendaño.- 4. El linaje Avendaño en la vida política del Reino y en las luchas sociales: de Martín Ruiz de Avendaño Tovar a Martín Ruiz de Gamboa y Avendaño.- 5. Epílogo conclusivo.

\section{INTRODUCCIÓN}

Mediante la realización de este artículo deseo ejemplificar algunas características de los miembros más encumbrados del estamento nobiliario en el País Vasco. Pretendo acercar al lector la nobleza solariega alavesa, guipuzcoana y vizcaína a través del examen de una casa de prestancia, la Casa de Urquizu, a cuyos señores los monarcas castellanos les nombraron Ballesteros Mayores del rey. El estudio sobre el linaje Avendaño se desarrollará siguiendo la evolución genealógica de los diferentes Parientes Mayores de la familia ${ }^{1}$. Desde esta perspectiva metodológica se valorarán las actividades sociales y políticas más significativas de quienes heredaron la Casa de Urquizu, el señorío de la villa de Villarreal de Álava, el oficio de Ballestero Mayor y el disfrute de los derechos de patronazgo de más de una veintena de iglesias parroquiales ${ }^{2}$. Estos datos sirven para que el lector adquiera una primera idea aproximada de la preponderancia señorial del linaje Avendaño.

El objetivo central de este texto es proporcionar una visión global de la biografía social de uno de los linajes principales del País Vasco durante los siglos XIV y XV. Tan sólo se aludirá a los "Grandes" de la Corona de Castilla o a otros caballeros solariegos vascos, si se relacionaron con el Pariente Mayor de la Casa de Urquizu, gracias al establecimiento de enlaces de parentesco, de pactos, alianzas o treguas diversas, o por todo lo contrario, cuando la enemistad, el odio o el hecho de formar parte del bando opositor favorecieron el choque de intereses contrapuestos y el enfrentamiento armado.

La promoción social y política de los señores de Villarreal de Álava se vio acompañada del incremento de sus rentas y derechos en el País Vasco, circunstancia que les impulsó igualmente a liderar, en momentos determina-

${ }^{1}$ Véase la genealogía del linaje Avendaño en el apéndice de cuadros y mapas del artículo.

${ }^{2}$ Véase el mapa $n^{\circ} 2$ en el apéndice de cuadros y mapas del artículo. 
dos, alguna de las propuestas políticas que cuajaron en los siglos que comprenden la Baja Edad Media y a otros linajes caballerescos en sus disputas con casas solariegas enemigas. Las guerras de bandos, en consecuencia, serán objeto de consideración específica, pues, no en vano, capitanearon el bando Gamboíno en el Señorío de Vizcaya. Los orígenes y las causas de estas luchas banderizas no serán valorados, sin embargo, en este trabajo de investigación. Los ingredientes de este conflicto, como es conocido por los medievalistas, fueron numerosos, se condimentaron con productos endógenos y exógenos, y fueron cocinados en una olla a presión imperfecta encendida en unos contextos políticos particularmente enrarecidos. Tampoco analizaré en esta ocasión el conjunto de instrumentos a los que recurrió la nobleza para afirmarse socialmente: los entresijos concretos del sistema hereditario, las características de la cartas de dote, como expresión de las alianzas linajudas, la posesión de casas torres y palacios, la consecución de señoríos jurisdiccionales y dominicales o los símbolos heráldicos ${ }^{3}$.

Por el contrario, mi intención en este artículo es ofrecer una panorámica general de la evolución del linaje de la Casa de Urquizu a través de la red familiar establecida y del protagonismo desempeñado por los diferentes Parientes Mayores en el transcurso de los siglos XIV y XV.

\section{LOS PRESUNTOS ORÍGENES DEL LINAJE}

La génesis del linaje Avendaño, salvando las distancias cronológicas, religiosas y políticas, tiene alguna similitud, aunque lejana, con el origen del emirato Omeya de Córdoba. Es sabido que todos los parientes del último califa Omeya, Marwân II, fueron asesinados por la nueva dinastía instaurada, la abásida, a excepción de Abderramán I (Abd ar-Rahmân ibn Mú-awiya), que logró escapar, refugiarse en el Magreb y fundar posteriormente un emirato independiente con sede en Córdoba a mediados del siglo VIII. Recuerda aún más a la primera parte del relato bíblico alusivo a un hijo de la tribu de Leví, Moisés, que siendo niño fue librado de una muerte segura, gracias a que una hija del faraón le recogió de las aguas donde había sido abandonado por sus padres, le protegió y se encargó de su educación.

\footnotetext{
${ }^{3}$ Un excelente repaso a estas cuestiones ha sido elaborado por Isabel BECEIRO PITA y Ricardo CóRDOBA DE LA LlaVE, Parentesco, poder y mentalidad. La nobleza castellana. Siglos XII al XV, Madrid, 1990.
} 
Las Bienandanzas e Fortunas, escritas en la segunda mitad del siglo XV por el caballero vizcaíno don Lope García de Salazar, cuentan que el linaje Avendaño procedía de una aldea alavesa llamada San Martín de Avendaño ${ }^{4}$. En dicha aldea, próxima a la villa medieval de Vitoria, radicaba la casa y morada de la familia Avendaño, enfrentada con el concejo de Vitoria, población perteneciente todavía al reino de Navarra. La destrucción de la casa y solar del linaje y la muerte de la mayoría de la familia, fue achacada a los vitorianos, si se da crédito al relato de Lope García de Salazar. Sólo se escapó de dicho desastre un niño de dos años llamado Pedro Ortiz de Avendaño, gracias a que la ama que lo criaba lo ocultó en la Merindad vizcaína de Arratia. El odio de los vitorianos hacia los Avendaño fue de tal envergadura que quisieron evitar el nacimiento de descendencia de la única persona de la familia que había quedado viva. Para ello acordaron con quienes le acogieron que debería dedicarse a la profesión eclesiástica. Muy al contrario de lo deseado, según las genealogías, este clérigo tuvo un hijo, don Juan Pérez de Avendaño, en doña Pascuala Sánchez de Zurbano, al que se hace responsable de que resurgiera de sus cenizas el ave fénix de los Avendaño. De proscritos alaveses a fines del siglo XII llegaron a ubicarse en la cúspide social de Vizcaya y también de Álava en la decimocuarta centuria. El relato es el siguiente:

Del solar e linaje de los de Avendaño de Vizcaya e donde suçedieron e suceden:

En el tiempo que la Villa de Vitoria era del Reyno de Navarra, avia un linaje de cavalleros en una aldea çerca della, que llamavan e llaman agora Sant Martin de Avendaño, que eran poderosos en la comarca e fasian continamente muchos enojos a los pobladores de Vitoria, de lo qual todo el dicho Conçejo se enviaron querellar al Rey de Navarra su señor, e fallaronlo en una huerta mirando con algunos cavalleros que estavan con el, como le dieron su querella, tomó el una espada al mensajero dellos e cortó con ella unas dies caveças de verzas e dixoles: vos los de Vitoria sodes para poco que a los que asi bos fatigan debriades les faser como yo fise a estas verças. Con esto se fueron a la dicha villa, e acordados en aquello, todo el pueblo levantaronse una noche e fueron sobre aquellos cavalleros de Avendaño que alli fasian su vivienda, e sus palaçios, e eredamientos que estavan descuydados, e quemaronlos e mataronlos a todos con fijos e con mugeres, e con toda su generaçión, si no un moço fijo del mayor dellos, que era de dos años, que fuyó una ama que lo criava con el,

\footnotetext{
${ }^{4}$ Todavía hoy puede contemplarse la ermita románica de San Martín de Avendaño, adosada a la iglesia parroquial del mismo nombre, en el Barrio de San Martín de Vitoria.
} 
e lo sacó de noche enbuelto en sus vestiduras, e fuese con el Arratia, e criolo alli don Sancho de Galdaçano, fijo del cavallero de Galdaçano, e creçido, e seyendo ya ome, ovo convençion con la dicha villa que tomase orden de la Yglesia, que no curase de fecho de cavallería e que entrase en la tierra, e fisieronlo Arçipreste de Alava, e salió ome para mucho, e tomó por mançeva una fija de Don Sancho Garçia de Çurbano, que era fijo de don Garci Sanches, fijo del Conde don Sancho, Señor de Vizcaya, que eredó a Orosco deste su padre; e fizo en ella a Juan Peres de Avendaño...5.

Unos años antes, la crónica de Vizcaya escrita por el mismo Lope García de Salazar a mediados del siglo XV (1454), narraba de forma algo diferente dicho acontecimiento. Afirmaba que el rey de Navarra, dirigiéndose a los vitorianos, mandoles que los matassen, refiriéndose a los miembros del linaje Avendaño y no aludía por ninguna parte a la existencia de un acuerdo previo entre la villa y la ama que le había recogido, la cual criolo callando, e por le quitar de roido prisolo a la Orden e fue arcipreste de toda Alava ${ }^{6}$.

Sin duda, estamos en presencia de un relato genealógico fantástico, como aconteció en muchos otros $\operatorname{casos}^{7}$, difícil de aceptar al pie de la letra, pero que debió obedecer a un contexto histórico probablemente verdadero. En todo caso, yo destacaría en el relato de Lope García de Salazar, dos nudos gordianos en la argumentación genealógica bajomedieval. El primero parece querernos convencer de que el linaje Avendaño tuvo unos orígenes hidalgos muy antiguos que se hacen trasladar a Álava y cuando menos se retrotraen a los años finales del siglo XII, en un contexto de rivalidad entre Vitoria y los principales linajes caballerescos del entorno de la Llanada Alavesa. El segundo pretende destacar y explicar el asentamiento de un miembro del linaje Avendaño en la Merindad de Arratia, comarca donde fueron propietarios de una casa solariega, la de Urquizu, en Yurre (Igorre), baluarte simbólico de su ascendencia hidalga ante el resto de la sociedad vizcaína y castellana en las centurias decimocuarta y siguientes.

Por otra parte, la genealogía de don Fernán Pérez de Ayala, elaborada en 1371, al referirse al linaje Avendaño es mucho menos novelada que la de Lope García de Salazar y hace arrancar los orígenes de esta familia a partir de Martín Pérez, hijo de don Pedro Ladrón de Guevara, señor de Oñate y

${ }^{5}$ Lope García DE SAlazAR, Las Bienandanzas e Fortunas. Edic. de Ángel Rodríguez Herrero, Bilbao, 1984, 4 vols.

${ }^{6}$ Sabino AguirRe GANDARIAS, Las dos primeras crónicas de Vizcaya. Bilbao, 1986, p. 87.

${ }^{7}$ Isabel BECEIRO PITA, El uso de los ancestros por la aristocracia castellana: El caso de los Ayala, "Revista de Dialectología y Tradiciones populares", 50/2 (1995), pp. 53-82. 
María Sánchez de Salcedo ${ }^{8}$. Pedro Martínez de Avendaño, hijo primogénito de Martín Pérez de Avendaño y el resto de sus hermanos habrían sido asesinados por los vitorianos. Sólo habría sobrevivido a la matanza Pedro Pérez de Avendaño que casó con doña Juana Sánchez de Zurbano. Juan Pérez de Avendaño, hijo de Pedro Pérez y de Juana Sánchez, tuvo al menos dos hijos. Don Fernán Pérez de Ayala tan sólo se refiere a una hija de Juan Pérez de Avendaño llamada María Pérez de Avendaño, que se casó con Ruy Pérez de Ayala "motila", de quienes habría nacido Juan López de Gamboa

que pobló en Çumaya en Guipúzcoa, e gano el monasterio de San Bartolomé de Olaso, e de Santa Maria de Plasencia e de San Andres de Eyvar e de San Martín de Çallurroa del rey don Alfonso que fue par de emperador. E fiço la casa de Olaso e fue el primero que puso hi cadalso e solar. E de aquí vienen los de Gamboa'.

El motivo de que don Fernán no hiciera alusión a otros hijos de Juan Pérez de Avendaño es obvio, pues tan sólo parece estar interesado en reflejar los parentescos anudados con miembros de su familia. Ruy Pérez de Ayala era hermano de su abuelo Sancho Pérez de Ayala. Sin embargo, don Fernán Pérez de Ayala afirma que los Múgica, Arteaga y Avendaño provienen del tronco de Juan Pérez de Avendaño. Lope García de Salazar desarrolla esta cuestión algo más, al hacer proceder los solares de Aramayona, Múgica, Arteaga y Urquizu de Pedro Ortiz de Avendaño, el hijo mayor de Juan Pérez de Avendaño, que se había casado con una hija de Pedro Ortiz de Aramayona.

Del texto de Fernán Pérez de Ayala se deriva la existencia de relaciones de parentesco entre la familia Avendaño, los Guevara, el linaje de Salcedo, los Ayala establecidos en Toledo, los Orozco y los Gamboa. Según esta versión genealógica, la Casa de Ayala procedente de Toledo ${ }^{10}$ y el linaje Avendaño no sólo tuvieron antepasados comunes, don Pedro Ladrón de Guevara y doña María Sánchez de Salcedo, sino que posteriormente ambas familias siguieron estableciendo lazos de parentesco, uno de los cuales dio origen a Juan López de Gamboa, primer señor solariego de Olaso y cabeza de

\footnotetext{
${ }^{8}$ Marqués de LozoyA, Introducción a la biografía del Canciller Ayala, Imprenta Provincial de Vizcaya, Bilbao, 1950.

${ }^{9}$ Marqués de LozoyA, Introducción a la biografía del Canciller Ayala, p. 160.

${ }^{10}$ Véase Ernesto García FernÁndeZ, El linaje del Canciller don Pero López de Ayala, en El linaje del Canciller Ayala. Canciller Ayala. Conmemoración del VI centenario, Vitoria, 2007, pp. 80-311.
} 
los Gamboa. Es evidente en el pasaje del padre del Canciller Ayala el sello gamboíno de todos los linajes citados.

Así lo cuenta don Fernán Pérez de Ayala:

...el Conde Don Pero Ladron su hermano, e vino de Aragon e tomo la tierra, e casó con Doña Maria Sánchez de Salcedo...E ovieron mas por fijo tercero a Don Martín Perez, e diole su padre a San Martín de Avendaño cerca de Vitoria en el rio Avendaño. E diole escudo de oro e banda negra de Guevara. E este Don Martín Perez ovo fijos a Don Pero Martinez e a sus hermanos, que mataron a tuerto, los de Vitoria con consejo del Rey Don.... de Navarra. E solo quedo un fijuelo deste Don Pero Martinez que ovo nombre Don Pedro Perez de Avendaño, que le salvo su ama en Arratia, e alli le crio Don Sancho de Galdacano, ca era hermano de su madre deste Don Pedro Perez. E este cobró la tierra e caso con Doña Juana Sánchez fija de Don San Garcia de Zurbano e desque fino su muger se fiço de orden e fue Arcipreste de Alava. E ovo en esta Doña Juana Sánchez a Juan Perez de Avendaño, onde vienen los Música, e los Arteaga, e los de Avendaño en Vizcaya, e en Alava..."11.

Además el relato de don Fernán tiene otras novedades que conviene destacar. En primer lugar, el fundamento de la casa de Urquizu tendría su origen en Pedro Pérez de Avendaño y Juana Sánchez de Zurbano, frente a Lope García de Salazar que los identifica como Pedro Ortiz de Avendaño y Pascuala Sánchez de Zurbano. En segundo lugar, presenta a don Martín Pérez de Avendaño, el abuelo de Pedro Pérez, como dueño de San Martín de Avendaño, cuya iglesia monasterial y los derechos a ella anejos le habrían sido donados por su padre don Pedro Ladrón de Guevara, señor de Oñate. Lope García de Salazar se limita a señalar que dicho linaje de caballeros vivía en la aldea de San Martín de Avendaño. Y en tercer lugar, al contrario que Lope García de Salazar, no se describe el casamiento de Pedro Pérez de Avendaño, nieto de Martín Pérez de Avendaño, con doña Juana Sánchez de Zurbano, como una ruptura de la supuesta obligación anteriormente contraída con la villa de Vitoria de dedicarse a la profesión religiosa. Al revés, tomó los hábitos de clérigo una vez fenecida su mujer.

En ambos relatos, sin embargo, se resalta que la destrucción por los vitorianos de la casa solariega de los Avendaño, situada junto a la iglesia de San Martín de Avendaño, fue el motivo del desplazamiento de esta familia a Vizcaya. Son bien conocidas la tensas relaciones existentes entre caballeros

\footnotetext{
${ }^{11}$ Marqués de LozoyA, Introducción a la biografía del Canciller Ayala, pp. 153-154.
} 
solariegos alaveses y los vecinos de Vitoria entre finales del siglo XII y mediados del siglo XIII. Ese debió ser el contexto que precipitó el abandono de la casa solariega de San Martín de Avendaño por la familia titular de la misma. De no menor interés es la coincidencia de criterios entre Fernán Pérez de Ayala y Lope García de Salazar, al conectar la ascendencia del linaje Avendaño con don Sancho García de Zurbano, presunto descendiente de los señores de Vizcaya. Ambos escritores reivindican a los poderosos Haro como otra de las raíces del árbol genealógico del linaje Avendaño.

\section{UN LINAJE DE CABALLEROS}

\section{AL SERVICIO DE LOS SEÑORES DE VIZCAYA Y DE LOS REYES DE CASTILLA:} DE Martín RuIZ DE AVENDAÑo a JuAN DE SaN JuAN DE AVENDAÑo

Las crónicas de la Corona de Castilla no son tan explícitas en lo que concierne al papel desempeñado por el linaje de Avendaño en los años que antecedieron a la conquista de Álava por los ejércitos castellanos en 1200. La documentación escrita correspondiente al siglo XIII tampoco ilustra sobre la presunta pujanza de esta familia en Vizcaya, donde si se da valor a las genealogías, había llegado a ser titular de las casas solariegas de Urquizu, Múgica y Arteaga, mientras que en el Norte de Álava habría heredado la casa solariega de Aramayona ${ }^{12}$. En mi opinión, el denominado linaje Avendaño estaba conformado en esas fechas por una familia hidalga de segunda fila, bien establecida en el solar de Urquizu (Arratia), barrio de la anteiglesia de Yurre (Igorre), donde se habría establecido hace ya algún tiempo. En consecuencia, esta noble familia no formó parte en el siglo XIII de la Cofradía de Álava, organización política controlada por los caballeros solariegos alaveses. El apellido Avendaño nunca es citado en las nóminas de cofrades alaveses conocidos.

\footnotetext{
${ }^{12}$ Lope García de Salazar afirma que Juan Pérez de Avendaño se casó con una hija del señor de Aramayona. El hijo de este matrimonio, Pedro Ortiz de Avendaño, poblaría Urquizu y heredaría Aramayona al no tener descendencia legítima el hermano de su madre, también llamado Pedro Ortiz. Entre los dos hijos varones de Pedro Ortiz de Avendaño se debieron repartir los solares de Urquizu, Aramayona, Múgica y Arteaga. Martín Ruiz de Avendaño heredaría Urquizu y Fortún García de Avendaño Aramayona, Múgica y Arteaga. Fortún García de Avendaño fue patrono de diversos monasterios, entre otros el de Santo Tomás de Arrazua.
} 


\section{Martín Ruiz de Avendaño y su hijo Juan Pérez de Avendaño: el despegue del linaje}

Un cambio bastante radical respecto a la situación precedente debió producirse en la primera mitad del siglo XIV. El matrimonio de Martín Ruiz de Avendaño y Mencía de Guevara es la punta del iceberg del reconocimiento del ascenso social del linaje. Sobre el particular resulta llamativo que don Fernán Pérez de Ayala no hiciera mención a Martín Ruiz de Avendaño en la redacción de su genealogía. Máxime si se tiene en cuenta que ambos tuvieron a los Guevara entre sus antepasados comunes y que el padre del Canciller Ayala era pariente de los Gamboa, debido a que su solar originario procedía de la unión matrimonial de Ruy Pérez de Ayala - tío abuelo de don Fernány doña María Pérez de Avendaño. Fernán Pérez de Ayala no debió simpatizar demasiado con los señores solariegos de la Casa solariega de Urquizu y sus primos de Aramayona, que apoyaron a Sancho García de Murga en sus pretensiones de heredar la Casa solariega de Quejana en Ayala ${ }^{13}$.En cualquier caso, el enlace conyugal contraído entre don Martín Ruiz de Avendaño y doña Mencía de Guevara, miembro del linaje de la Casa de Guevara, señores de Guevara y de Oñate ${ }^{14}$, facilitó la promoción de la Casa de Urquizu entre el resto de las principales familias nobiliarias del reino de Castilla. A su vez su buena sintonía con el señor de Vizcaya, don Juan Núñez de Lara y su mujer doña María Díaz de Haro, pues doña Mencía de Guevara fue aya de su hijo don Nuño en $1351^{15}$, convirtieron a Martín Ruiz de Avendaño en uno de sus más fieles servidores en el Señorío.

En este contexto de ascenso social sale a la palestra, Juan de Avendaño, su hijo primogénito, que aparece recogido en las Bienandanzas $e$ Fortunas de Lope García de Salazar como un personaje agresivo y ambicioso. En 1337 Juan de Avendaño fue inculpado a causa de haber asesinado por

\footnotetext{
${ }^{13}$ Así lo cuenta Fernán Pérez de Ayala en su genealogía de 1371: “...E empues desto vino Fortun García de Avendaño con sus parientes, e con otros 200 ballesteros que le dieron los de Salcedo, e posieron celada a Don Sancho Perez en las Montañas de Llanteno onde sabien habie de pasar. E Don Sancho Perez non venie apercevido, si non con pocos. E corrio con su cavallo fasta cerca de Nuestra Señora de Respaldiza, onde malamante le mataron. Dios le de Santo Paraiso Amen".

${ }^{14}$ El propio Martín Ruiz de Avendaño procedía asimismo de una lejana unión matrimonial entre Pedro Ladrón de Guevara, señor de Oñate y doña María Sánchez de Salcedo. Ahora de nuevo se producía una intersección conyugal de carácter endogámico.

${ }^{15}$ Pedro López de Ayala, Crónica del rey don Pedro. Año segundo. 1351. Cap. VII. T. LXVI, p. 415.
} 
envidia a su primo Pedro Ortiz de Avendaño, presunto señor de Aramayona e hijo de Fortún García de Avendaño. En 1342 es acusado de haber atacado a la villa de Bilbao:

...En el año del Señor de U CCCXLII (1342) años, este Juan de Avendaño, seyendo ome mucho vulliçioso, e guerrero, e para mucho, fasia guerra al conçejo de Vilvao, de un castillo que tenia en un otero sobre las veneras de Bilbao, que llamavan Malpica, e salieron los de la villa todos, e pelearon con el açerca del castillo, e fueron vençidos e corridos fasta la puente de la Villa, e quedaron muchos muertos dellos, e dexaron muchas $\operatorname{armas}^{16}$.

Está claro que el linaje Avendaño estaba bien posicionado en el entorno de la ría de Bilbao a finales del reinado de Alfonso XI y con sus sucesores en el trono de Castilla, como lo demuestra la posesión en 1342 de la fortaleza de Malpica, ubicada en una atalaya, desde donde Juan de Avendaño organizaba y dirigía ataques a los vecinos de la villa, según Lope García de Salazar.

Aún no se ha podido documentar el momento preciso en que el linaje Avendaño pudo haber adquirido dicha casa torre. No obstante, del control de una casa torre, situada cerca de la margen izquierda de la ría y al otro lado de la villa de Bilbao, se derivan, al menos, dos consecuencias. La primera que los dueños del solar de Urquizu no se despreocuparon de la nueva realidad económica, social y política, generadas al son del reciente desarrollo urbano de Bilbao. Y la segunda que el Pariente Mayor del linaje Avendaño se había constituido para mediados del siglo XIV en una de las casas solariegas más poderosas del Bajo Nervión y del Señorío de Vizcaya. Ciertamente por estos años el solar de Urquizu es la raíz del árbol del linaje, pero desde sus largas ramas se divisa la ría del Nervión y la propia villa de Bilbao. De esta manera se comprende mejor la relación de los Avendaño con los linajes caballerescos bilbaínos y la reiterada injerencia del linaje Avendaño en la villa de Bilbao. En 1351, Juan de Avendaño, era alcaide de la fortaleza de Unceta (Orozco) por delegación del señor de Vizcaya y la guarnición allí asentada resistió durante dos meses el asedio militar de los ejércitos del monarca castellano, Pedro I. A continuación don Fernán Pérez de Ayala recuperó en las

${ }^{16}$ Lope GaRCía de SALAZAR, Las Bienandanzas e Fortunas, vol. IV, pp. 180-181. 
Encartaciones el denominado castillo de Aranguti ${ }^{17}$, núcleo de resistencia a las pretensiones del rey de Castilla.

Don Tello, hermanastro de Pedro I de Castilla, fue el nuevo señor de Vizcaya, tras esposarse con Juana Núñez de Lara y Díaz de Haro. En un primer momento se mantuvieron los lazos de amistad con el Pariente Mayor de la Casa de Urquizu, Juan de Avendaño, que en 1353, al unísono con su hermano Juan de San Juan de Avendaño, acordó con el concejo de Bilbao una tregua perpetua de no agresión entre ambas partes

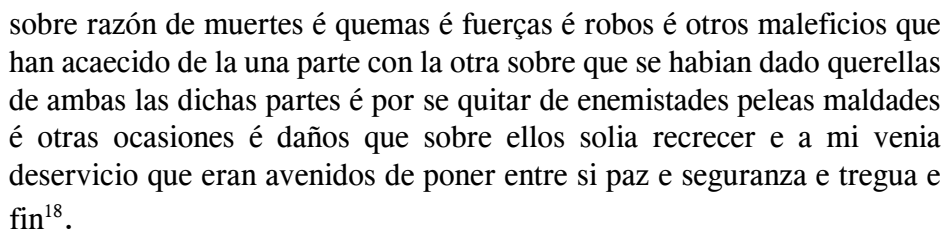

En 1355 los partidarios del infante don Juan de Aragón reclamaron el señorío de Vizcaya, pero fueron derrotados en las Encartaciones y en Ochandiano, donde se hallaban dirigiendo la resistencia Juan Hurtado de Mendoza y Juan de Avendaño.

El 21 de junio de 1356 Juan Pérez de Avendaño es mencionado el primero de los caballeros, escuderos, fijosdalgo de Vizcaya que se compromete a aceptar como señor de Vizcaya al rey don Pedro I de Castilla, en el caso de que don Tello rompiera sus lealtades hacia el monarca castellano. Por entonces la tensión política existente en Castilla era enorme. La nobleza estaba dividida debido a las decisiones políticas y personales adoptadas por Pedro I. Los hermanastros del rey y sus primos, los infantes de Aragón (Fernando y Juan), se habían posicionado en contra de las relaciones maritales del rey con María de Padilla. Ante este estado de cosas, los pobladores de Vizcaya planearon una situación de compromiso para evitar la invasión del Señorío por las tropas realengas. Estanislao Labayru afirma que Juan de Avendaño, Prestamero Mayor de Vizcaya, oficio de gran relevancia en el Señorío de

\footnotetext{
${ }^{17}$ Estanislao de LABAYRU, Historia General del Señorío de Vizcaya, Bilbao, 1967-1968, vol. II, pp. 360-361.

${ }^{18}$ Estanislao de LABAYRU, Historia General del Señorío de Vizcaya, vol. II, pp. 363-367. Entre los numerosos parientes y partidarios de Juan de Avendaño se cita asimismo una persona con el nombre de Juan López de Gamboa é sus compañeros.
} 
Vizcaya, debió estar detrás del pacto suscrito por los vizcaínos en 1356, pues había escrito al rey que faria como Don Tello viniese á la su merced ${ }^{19}$.

Ese mismo año don Tello acabó con la vida de Juan de Avendaño supuestamente a causa de una altanería y arrogancia que no quiso soportar ${ }^{20}$. Más bien da la impresión que detrás de esta muerte se hallaron también las dificultades de Juan de Avendaño para conciliar las fidelidades hacia el rey de Castilla, Pedro I, y hacia el señor de Vizcaya, don Tello de Trastámara. Lope García de Salazar lo relata de la siguiente manera:

En el año del Señor de U CCCLVI (1356) años, mató el Conde don Tello, Señor de Vizcaya, a este Juan de Avendaño, en la Villa de Vilvao, dentro de su palaçio, e echolo de las ventanas a la plaça, e la causa de su muerte fue porque fazia muchas osadias en Viscaya e no preçiava nada al Señor en Viscaya e no preçiava nada al Señor; e la postrimera causa de su muerte fue porque este Conde don Tello, que era mucho montero, tenia dose puercos monteses en Alviña, e echolos en la plaça de Vilvao, e cavalgó en un cavallo, e nunca lo pudo meter entre ellos espantandosele dellos, e dixole aquel Juan de Avendaño, Señor, dexadme cavalgar en ese cavallo e yo lo faré saltar sobre ellos a pesar de si, e diogelo e cavalgó en el. E como era ome endiablado, pusole las espuelas e fizole saltar sobre aquellos puercos, e tropeçando en ellos, cayeron anbos en tierra, e levantose el cavallo con el, e tornó otra ves sobre ellos, e fizolo saltar de parte en parte, e dixo contra el Conde, como en solas a rruyn malandante yo fuera para Señor de Vizcaya. E descavalgando, e suvido el Conde a comer, no faltó quien le dixo que no era para en el mundo si tales cosas soportava, e unos de los prinçipales fue Pedro Roys de Leçama, que le andava por tomar a doña Elvira, su muger, que era mucho fermosa e loçana, sobejamente, sobre todas las de su tiempo de Viscaya, e siempre la tenia guardada en la su torre de Leçama con criados suyos por este reçelo. E veniendo este Juan de Avendaño al palaçio despues de comer, fue luego muerto a porradas, e echado por las ventanas a la calle como dicho $\mathrm{es}^{21}$.

La carrera política de Juan Pérez de Avendaño le deparó amargas y trágicas desventuras. Juan Pérez de Avendaño queriendo ser fiel al señor de

\footnotetext{
${ }^{19}$ Estanislao de LABAYRU, Historia General del Señorío de Vizcaya, II, pp. 374-376. Los otros linajes principales citados en dicho documento son Gómez González de Villela, Ordoño de Zamudio, Fortún Sánchez de Zumelzu, Adán de Yarza, Pedro Ruiz de Lezama, Juan Sánchez de Meceta, Rui Martínez de Albiz, Iñigo Ortiz de Albiz, Sancho Sánchez de Zumelzu, Gonzalo Ibáñez de Arancibia, Lope Ibáñez de Marquina, Sancho Ibáñez de Atucha, Juan Sánchez de Villela, Fortún Sánchez de Guecho, Juan Alonso de Múgica, Ochoa Martínez de Marzana y Juan Martínez de Ibargüen.

${ }^{20}$ Lope García DE SAlAZAR, Las Bienandanzas e Fortunas, Libro XXII, folio 39.

${ }^{21}$ Lope GARCíA DE SAlAZAR, Las Bienandanzas e Fortunas, vol. IV, pp. 181-182.
} 
Vizcaya, Juan Núñez de Lara, se granjeó la enemistad de Pedro I. Más tarde, quizá también por haberse acercado a las posiciones políticas del monarca castellano, murió a manos de don Tello, el nuevo señor de Vizcaya.

\section{Juan de San Juan de Avendaño: el nuevo señor de la Casa de Urquizu}

El asesinato de Juan de Avendaño posibilitó que su hermano Juan de San Juan de Avendaño accediera al señorío de la casa de Urquizu. Juan de San Juan de Avendaño fue uno de los caballeros vizcaínos que apoyó a Enrique de Trastámara, en su rebeldía con su hermanastro el rey Pedro I de Castilla. Las ideas políticas de Juan de San Juan de Avendaño eran más protrastamaristas que las de su hermano, Juan de Avendaño. La victoria de Enrique, que designó a Juan de San Juan de Avendaño, Ballestero Mayor suyo y la fidelidad a su causa tuvo como efecto el encumbramiento del linaje hasta cotas no alcanzadas hasta la fecha. Enrique II le concedió en 1371 el señorío de Villarreal de Álava, villa aforada en 1338 por Alfonso XI de Castilla. Juan de San Juan de Avendaño, durante el reinado de Juan I de Castilla, junto con Diego Sánchez de Rojas, fue designado miembro de la Audiencia de Castilla en representación de los hidalgos del Reino en las Cortes de Segovia de 1390. El desempeño de este oficio da una idea clara de las conexiones que mantenía el Pariente Mayor de la Casa de Urquizu con la Corte y en el conjunto de la Corona de Castilla con los caballeros, grupo al que pertenecía.

En 1391 Juan de San Juan de Avendaño fue uno de los cuatro caballeros vizcaínos que, siendo menor de edad Enrique III, comprometieron al monarca para que hiciera juramento de que se desplazaría lo antes posible a Vizcaya para jurar sus fueros, privilegios, buenos usos é buenas costumbres, libertades mercedes y tierras, según se acostumbró por los otros señores. Este acto se llevó a cabo en el altar de la capilla del Castillo de Burgos en presencia de los tutores del rey y de Juan de San Juan de Avendaño, Juan Alonso de Múgica, Gonzalo Gómez de Villela y Juan García de Areilza ${ }^{22}$. El acontecimiento refleja la distinción social del linaje Avendaño en las tierras vizcaínas. En esta embajada no aparecen representantes de las villas, sino tan sólo caballeros de la Tierra Llana, que se preocuparon de recordar al monarca que Vizcaya estaba exenta del pago de tributos a los obispados de Burgos y Calahorra. De esta manera protegían sus derechos de patronazgo. Dos años

\footnotetext{
${ }^{22}$ Estanislao de LABAYRU, Historia General del Señorío de Vizcaya, vol. II, pp. 479-480.
} 
después, en 1393, el monarca acudió al Señorío de Vizcaya a jurar los fueros a los vizcaínos. Probablemente en 1394, las hermandades vizcaínas se levantaron contra la presunta prepotencia ejercida en el Señorío por los linajes Arteaga, Butrón y dos de los linajes que se dirigieron a Burgos (Avendaño y Múgica). Lope García de Salazar describe dicho levantamiento, si bien lo fecha unos años antes en 1390:

\begin{abstract}
DE CÓMO SE LEVANTARON LAS ERMANDADES DE VIZCAYA CON EL DOTOR GONZALO MORO E DE LA CAUSA PORQUÉ

En el año del Señor de U CCCXC (1390) años, se levantaron las Hermandades en toda Viscaya con el doctor Gonzalo Moro, corregidor de Viscaya, por mandado e favor del Rey don Enrique terçero, e durando esta Hermandad, levantaronse Vizcaya e la Encartaçion, Villas e tierra llana, e una ves no quisiendo pagar los pedidos al Rey, fasta que les veniese faser juramento a Gernica, e a Vermeo, segund los Reyes pasados de les guardar sus franquesas e libertades, porque Juan de Sant Juan de Avendaño, e Juan Alonso de Mugica, e Gonzalo Gomes de Butron el viejo, e Martin Rois de Arteaga, tomaron libramiento en sus tierras del Rey, e ovieron convençion en uno de ayudarse a lo tomar, e por esto levantose toda Vizcaya contra ellos, e desanpararonlos todos los parientes, que no les quedaron ningunos porque no le quedaron ningunos, por manera que Juan Sanches de Villela e Martin Ochoa de Laviero, que eran dos omes, entendidos, gobernavan todas las dichas Ermandades, e allegavalos el dicho dotor Gonzalo Moro, mucho asi, e eran alcaldes de fuero anbos a dos, e todos estos cavalleros fue mas quexado Gonzalo Gomes de Butron, porquel començo a prendar el primero, e en tanto estrecho lo posieron, que no quedaron con el mas de XIII omes de su casa e linaje, e sobre todos lo persiguia aquel Juan Sanches de Villela ${ }^{23}$.
\end{abstract}

Juan de San Juan de Avendaño logró para la Casa de Urquizu títulos honoríficos de relevancia (Ballestero Mayor del rey), gozó de prestigio en el sector social de los caballeros de la Corona de Castilla, abanderó la reivindicación de las exenciones fiscales de los vizcaínos repecto a las dos diócesis que se repartían el Señorío de Vizcaya e incorporó al mayorazgo del linaje la villa y aldeas de Villarreal de Álava.

\footnotetext{
${ }^{23}$ Lope GaRCía DE SAlAZAR, Las Bienandanzas e Fortunas, vol. IV, pp. 183-184.
} 


\section{El LINAJE AVENDAÑo EN LA VIDA POLÍTICA DEL REINO \\ Y EN LAS LUCHAS SOCIALES: \\ DE MARTín RUIZ DE AVENDAÑo TOVAR \\ A MARTÍN RUIZ DE GAMBOA Y AVENDAÑO}

\section{Martín Ruiz de Avendaño Tovar: un avezado marinero implicado en empresas de la monarquía castellana}

El servicio a los reyes castellanos exigió a los Parientes Mayores del linaje pasar gran parte del tiempo fuera de las tierras donde poseyeron sus señoríos y tuvieron su casa solariega. El sucesor de Juan de San Juan de Avendaño fue Martín Ruiz de Avendaño, cuyo nombre emulaba el de su abuelo. Éste último había adoptado a su vez el nombre y la primera parte del apellido de su abuelo materno (Martin Roys de Gautiques). Martín Ruiz de Avendaño fue un hombre activo comprometido con las empresas terrestres y marítimas de la monarquía castellana. Fernán Sánchez de Tovar, su abuelo, capitaneó en 1359 una galera de la flota dirigida contra Pedro I de Aragón en el Mediterráneo y su tío abuelo homónimo, fue almirante de Castilla entre 1373 y 1384. La historiografía sostiene que Martín Ruiz de Avendaño pudo haber llegado en uno de sus viajes a la isla de Lanzarote a finales del siglo $\mathrm{XIV}^{24}$. La leyenda insiste en su presencia en la isla, donde tuvo una hija llamada Ico, fruto de las relaciones que mantuvo con Fayna, mujer del rey Zonzamas, el cual le habría acogido en su casa a su llegada ${ }^{25}$. En 1397, aparece Martín Ruiz de Avendaño al servicio de don Diego Hurtado de Mendoza, almirante de Castilla y persona que casó a dos presuntas hijas

${ }^{24}$ Maximiano, García Venero, Canarias. Biografía de la región Atlántica. Madrid, 1962, pp. 77-83; Juan ÁlvarEZ DELGado, Episodio de Avendaño. Aurora histórica de Lanzarote, La Laguna, 1957; Rafael SÁNCHEZ SAUS, El almirantazgo de Castilla y las primeras expediciones y ayuntamientos en Canarias, "En la España Medieval", 28 (2005), pp. 177-195 y Eduardo AZNAR VALLEJo, Los itinerarios atlánticos en la vertebración del espacio hispánico. De los Algarbes al Ultramar Oceánico, en "XXVII Semana de Estudios Medievales, Estella 2000", Pamplona, 2001, pp. 47-82. 1978.

${ }^{25}$ J. de ABREU GALINDO, Historia de la conquista de las Siete Islas de Canarias. Tenerife, 
bastardas con linajes sevillanos que enraizaron en las Islas Canarias ${ }^{26}$, en operaciones navales realizadas en las costas de Galicia contra los portugueses.

Unos años después, en 1405, le designaron capitán de una flota de barcos dispuesta a socorrer a los reyes franceses y a los transportistas y mercaderes que realizaban sus operaciones comerciales a través del Golfo de Vizcaya de las acometidas de los corsarios ingleses. Está documentada su estancia en Harfleur junto a don Pero Niño ${ }^{27}$. Poco antes de su muerte disputó a Fernán Pérez de Ayala sus derechos sucesorios a la casa solariega de Orozco por descender Martín Ruiz de Avendaño de Sancho García de Zurbano. Se llegó a un acuerdo entre ambos Parientes Mayores. Orozco y Llodio quedaron para la Casa de Ayala, mientras que Arrigorriaga y Marquina de Zuya fueron incorporados por la Casa de Urquizu ${ }^{28}$. Murió a principios del siglo $\mathrm{XV}$, según algunos historiadores en la batalla de Antequera $(1410)^{29}$ y según otros en torno a $1413^{30}$.

\section{Juan de Avendaño López de Gamboa: su interés por posicionarse adecuadamente en las dinámicas villas de Vitoria y Bilbao}

A Martín Ruiz de Avendaño le sucedió en el señorío de Urquizu y de Villarreal de Álava, su hijo Juan de Avendaño y Gamboa, pues su padre se había casado con doña María López de Gamboa, hija de Juan López de Gamboa, señor de la Casa de Olaso y patrón de los monasterios de San Bartolomé de Olaso, Santa María de Plasencia, San Andrés de Eibar y San

\footnotetext{
${ }^{26}$ Rafael SÁNCHEZ SAUS, El almirantazgo de Castilla y las primeras expediciones, pp. 186 y ss. Véase asimismo el trabajo de José Manuel CALDERÓN ORTEGA, La intervención de marinos cántabros y vascos en la campaña naval de 1430 y los intentos por extender la jurisdicción del Almirantazgo de Castilla a los puertos del norte peninsular, "Itsas Memoria. Revista de Estudios Marítimos del País Vasco". 5 (Donostia, 2006), pp. 53-67.

${ }^{27}$ Luis SUÁREZ FernámNDEZ, Navegación y comercio en el Golfo de Vizcaya. Un estudio sobre la política marítima de la Casa de Trastámara, Madrid, 1959; Manuela RONQUILLO RUBIO, Los vascos en Canarias durante la época señorial, "Actas del XV Coloquio de Historia CanarioAmericana (2002)", Las Palmas, 2004 y Gonzalo DíEZ DE GAMES, El Victorial. Crónica de don Pero Niño, Madrid, 1989, pp. 136, 172, 175 y 201.

${ }^{28}$ Lope GARCía DE SALAZAR, Las Bienandanzas e Fortunas, vol. IV, pp. 254-255.

${ }^{29}$ Micaela PORTILla, Torres y casas fuertes en Álava, Vitoria, 1978, 2 vols; Estanislao de LABAYRU, Historia General del Señorío de Vizcaya, Bilbao, 1967-1968 y José Ángel García de Cortázar Arízaga; Beatriz ARízAGA; M ${ }^{\mathrm{a}}$ Luz Ríos; Isabel del VAL VALDIVIESO, Vizcaya en la Edad Media. Evolución demográfica, social y política de la comunidad vizcaína medieval, vol. III, San Sebastián, 1985 , p. 383.

${ }^{30}$ Rafael SÁNCHEZ SAUS, El almirantazgo de Castilla y las primeras expediciones, p. 179 y Manuel RoNQUILlo RUBIO, Los vascos en Canarias. Estos autores opinan que quien habría muerto en 1410 fue su nieto del mismo nombre.
} 
Martín de Zallurroa. A principios del siglo XV, en torno a 1411, Juan de Avendaño estuvo apoyando a los Leguizamón en las disputas que tenían con los Arbolancha en la villa de Bilbao ${ }^{31} \mathrm{y}$ al doctor Gonzalo Moro, corregidor de Vizcaya, acosado por las quejas y protestas de las hermandades vizcaínas ${ }^{32}$. Unos años más tarde, en 1414, los Leguizamón se aliaron con los Butrón y los Avendaño con los Arbolancha ${ }^{33}$. Ésta última alianza tuvo una mayor duración que la establecida previamente con los Leguizamón. Por tanto, en apenas 3 años se habían alterado las treguas fijadas anteriormente entre los Parientes Mayores bilbaínos y los Parientes Mayores solariegos.

Juan de Avendaño, en torno a 1421, se alineó con los Velasco para domeñar la rebeldía de los pobladores de algunas comarcas castellanas sujetas hasta esa fecha a derechos de behetrías para con dicho linaje ${ }^{34}$. Si los gamboínos fueron partidarios de los Velasco, la Casa de Ayala y los oñacinos, por el contrario, prefirieron apoyar al infante don Juan y a quienes se habían rebelado contra el linaje Velasco. Finalmente el triunfo se puso de parte del linaje Velasco. Precisamente en 1429 Pedro de Velasco, Camarero Mayor del rey, convocó a los principales señores de solares en Vizcaya, para defender

\footnotetext{
${ }^{31}$ De cómo entró Juan de Avendaño en la villa de Vilvao, e Juan Lopes de Gamboa con él, e de las peleas que obieron con los de Butrón.

En el año del Señor de U CCCCXI (1411) años, entró Juan de Avendaño, fijo de Martin Ruys de Avendaño, en la Villa de Bilbao, con poderosa gente, e tenia por el al linaje de Ligiçamon, e çercó a Ochoa Peres de Arvolancha en la torre de la plaça de Juan Sanches de Arvolancha, su hermano, e estaban con ellos los de Asua e Susunaga, e Gecho, e pelearon a la entrada de la Villa, e fueron muertos e feridos muchos onbres de anbas las partes, e fue ferido el dicho Juan de Avendaño con una saeta por los guargueros en lo vasio, e no ovo peligro, e vino doña María Alonso, muger de Gonzalo Gomes de Butron con todo el solar en su socorro, porque Gonzalo Gomes era en la Corte, e pusose en la Talaya de Bilbao e en la Renteria, e vino en ayuda de Juan de Avendaño, Juan Lopes de Gamboa, su aguelo. E otrosi, vino en ayuda de los de Butron Furtud Garcia de Arteaga, su yerno, e estando alli escaramuçando noches e dias, vino Gonzalo Gomes de Corte, e fiso el Dotor Gonzalo Moro treguas del Rey, e esparsieronse todos a sus comarcas. Lope GARCía DE SALAZAR, Las Bienandanzas e Fortunas, vol. IV, p. 187.

${ }^{32}$ Lope García DE SALAZAR, Las Bienandanzas e Fortunas, vol. IV, pp. 193-194.

${ }^{33}$ Lope García de SAlaZar Las Bienandanzas e Fortunas, vol. IV, pp. 191-193.

34“"DE LAS GENTES QUE SE JUNTARON EN MEDINA, A FAVOR DE LA CASA DE VELASCO E DE LAS COSAS QUE ALLI PASARON EN TODAS ESTAS ASONADAS

Juntaronse con la casa de Velasco los Giles todos, e algunos Negretes, e de Salasar, e los Anguleses e Velascos de Mena, e los Gamboanos, e Juan de Avendaño. Juntaronse en Medina, ca no tenian poderio para salir a campo con las otras gentes, que eran muchas e grandes. Un dia juntaronse todos de la parte del dicho Ynfante a çerca de Medina, sus batallas puestas e ordenadas, pensando que les salerian a campo, los otros salieron de la villa, e pusieron sus batallas juntas con la dicha villa, e estovieron asi todo el dia fasta la tarde, e tornaronse a sus estançias, e duraron estas asonadas XL dias, e venieron un alcalde del rey, e un secretario e fesieron las treguas, e esparsiose la gente toda, e quedó la tierra robada de mala manera pero depues quedose la casa de Velasco con todo el Señorío e Merindades, segund se lo avia dexado el dicho Juan de Velasco, e aun con mas". Lope GARCÍA DE SALAZAR, Las Bienandanzas e Fortunas, vol. IV., pp. 257-258.
} 
las fronteras de Castilla con Navarra desde la villa de Briones (La Rioja). Acudieron a su llamada Gonzalo Gómez de Butrón, Fortún García de Arteaga y Juan de Avendaño con unos 3.000 hombres de a pie. Esta tropa, de ballesteros y lanceros, juntamente con otros 500 soldados que se hallaban a las órdenes de don Pedro de Velasco cercaron y asaltaron la villa, entonces inserta en el Reino de Navarra, de San Vicente de la Sonsierra

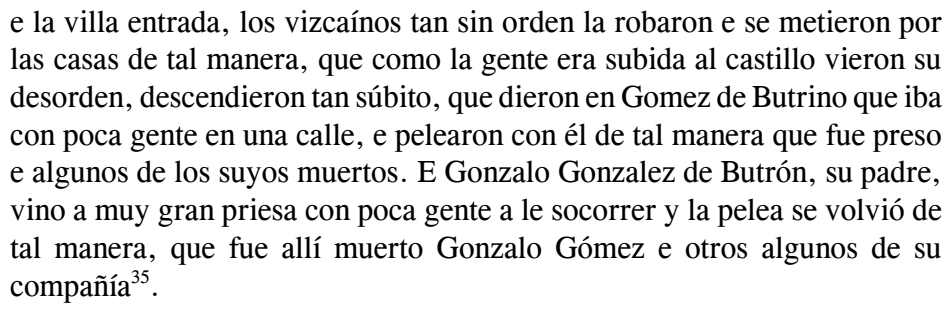

A principios del año 1429, Juan de Avendaño, Ballestero Mayor del rey, que estaba en Vitoria con un séquito de gentes armadas, se debió implicar en las disputas banderizas ocasionadas entre los dos bandos de la villa, el de los Ayala y el "de la Calleja". La historiografía ha sospechado que su entrada en dicha población estaría relacionada con su auxilio a los Ayala vitorianos, pues eran gamboínos, como él.

Lo cierto es que el concejo y otras gentes de Vitoria, ante los escándalos que se habían originado en la población por la división existente entre los miembros del linaje "de la Calleja" respecto a las elecciones municipales, acordaron tomar medidas drásticas con el fin de favorecer el nombramiento de los nuevos oficiales. Se decidió que fueran desterrados de la localidad cinco personas de cada una de las partidas que estaban en litigio y que cumplia a serviçio del Rey et a bien et provecho e union desta dicha su villa en que el dicho Juan de Abendagnu parta desta dicha villa con su gente et baya donde le ploguiese. A Juan de Avendaño no le gustó en absoluto el requerimiento que le hicieron los dirigentes de la villa de Vitoria, y consideró una injuria que le relacionaran con Angebín Sánchez de Maturana, miembro destacado del bando de "la Calleja", y con sus partidarios. No obstante, acató lo solicitado por los alcaldes y regidores

${ }^{35}$ Crónicas de los reyes de Castilla, Madrid, 1953, vol. II, pp. 474-475. 
non embargante que lo abian a injuriar por lo querer igualar con la otra parte del dicho Angebin Sanches en el salir de la dicha villa pero que por serviçio de Dios e del Rey e por complacer al dicho conçejo que le plasia siendo antes que los sobredichos dixo que non era rason ni paresçia bien de igualar a el con los sobredichos ${ }^{36}$.

Por otra parte, en Bilbao, el linaje Avendaño no quiso cejar en su empeño por influir en la vida política local durante los primeros años del siglo $\mathrm{XIV}^{37}$. De hecho en las ordenanzas de 1435 se prohibió que los vecinos de la villa entraran en las treguas de los Butrón y Avendaño. Con esta medida se intentó evitar las alianzas entre los linajes urbanos y los caballeros solariegos. Las ordenanzas de Bilbao de 1435 informan sobre el tipo de alianzas establecidas por esos años entre los Butrón y Avendaño con los Parientes Mayores de la villa. En este año se alude a la colaboración de Juan de Avendaño con las familias Zurbarán, Arbolancha, Basurto, Barraondo y Anuncibay, mientras que los Butrón lo hacían con los Leguizamón:

...los sobre dichos linajes e bandos de la dicha villa especialmente los del linaje de leguicamo tenian e tienen su lianca e ayuntamento con Gomes de Butron e con los de sus treguas e con Ochoa de Salazar e con los de sus treguas e con los de las treguas de Solar de Salcedo e con los ospines e otrosi los sobre dichos de Çurbaran e de Arbolancha e Basurto e Martín Sánchez de Barraondo e Martín e Diego de Anunçibai vecinos de la dicha villa e tenian e tienen sus liancas e confedereçiones con Johan de Bendaño e Furtun Garcia de Artiaga e con los de sus treguas e con Lope de Iñigo Sánchez de Nuncibay e con los de sus treguas e con los Marroquines e de sus treguas... ${ }^{38}$.

${ }^{36}$ José Ramón DÍAz DE DURANA, Vitoria a fines de la Edad Media, Vitoria, 1984, páginas 262-264 del apéndice documental. Según el documento 20 hombres ballesteros y lanceros de Juan de Avendaño llegaron a acosar el día anterior al regidor Fernán Ibáñez de Peñacerrada, mientras estaba reunido, tranquilamente en su casa, con clérigos de Treviño.

${ }^{37}$ Véase el mapa $\mathrm{n}^{0} 1$ del apéndice de cuadros y mapas.

${ }^{38}$ Ordenanzas de Bilbao de 1435. 


\section{Pedro de Avendaño Manrique de Lara: el período más conflictivo del linaje}

La muerte en 1436 de Juan de Avendaño ${ }^{39}$, casado con doña Teresa Manrique de Lara, hija del Adelantado Mayor de Castilla Gómez Manrique ${ }^{40}$, supuso el paso de la titularidad de la casa de Urquizu a su hijo Pedro de Avendaño y Manrique de Lara, que contrajo matrimonio con doña Leonor de Mendoza $^{41}$, hija de Juan Hurtado de Mendoza, prestamero Mayor de Vizcaya y de doña María de Rojas. Las relaciones de parentesco con los Prestameros del Señorío dieron prestancia y más poder al linaje Avendaño en Vizcaya y en los territorios adyacentes. Esta circunstancia le hizo más poderoso ante los ojos de los pobladores alaveses, vizcaínos y en menor medida guipuzcoanos en una coyuntura política conflictiva, la vivida especialmente durante los reinados de Juan II y de Enrique IV de Castilla.

En esta época tanto Pedro de Avendaño y Manrique de Lara, como su hijo Juan de Avendaño y Mendoza, estuvieron reiteradamente enfrascados en las luchas de bandos acaecidas principalmente en Vizcaya y Álava, sobre todo con sus más acérrimos enemigos, los Butrón y los Múgica. En 1437 los Butrón cercaron la torre que Pedro de Avendaño poseía en Ochandiano y ese mismo año el linaje Avendaño se hacía con la fortaleza de Barajuen en Aramayona, gracias a que hidalgos locales, los Garay y Urréjola, habían buscado su protección frente a Gómez González de Butrón contra quien se

${ }^{39} \mathrm{La}$ carencia de descendencia masculina del señor de Olaso significó que Fernando de Avendaño y Gamboa, hermano de Juan de Avendaño, fuera designado señor de Olaso.

${ }^{40}$ Véase sobre dicho personaje el artículo de Alfonso FrANCO Silva, La fortuna del Adelantado Mayor de Castilla Gómez Manrique, en "La fortuna y el poder. Estudios sobre las bases económicas de la aristocracia castellana (s. XIV-XV)". Cádiz, 1996, pp. 355-377 y el libro de Rosa María MONTERo TEJADA, Nobleza y sociedad en Castilla. El linaje Manrique (siglos XIV-XVI). Madrid, 1996. Gómez Manrique (c. 1356-1411) — casado con Sancha de Rojas, hija de Ruy Díaz de Rojas y María de Guevara, así como Adelantado Mayor de Castilla desde el año 1385-, fue señor de Frómista e hijo bastardo de Pedro Manrique, señor de Amusco (Palencia). Gómez Manrique ordenó en su testamento de 1410 que le enterraran en el monasterio de Santa María de Fresdeval. Teresa Manrique, hija de Gómez Manrique, se casó en primeras nupcias con Juan de Avendaño y en segundas con Juan de Aróstegui, que según el inventario de bienes realizado por Sancha de Rojas en 1413 habría de percibir Villalba de Losa con sus aldeas, la mitad de los bienes y molino de Pancorbo, así como la casa torre y las heredades de Hurones.

${ }^{41}$ Leonor de Mendoza, según José Ángel García DE CORTÁZAR; Beatriz ARíZAGA; M ${ }^{a}$ Luz Ríos; Isabel del VAL VALDIVIESO, Vizcaya en la Edad Media. Evolución demográfica, social y política, III, p. 383, que siguen a Estanislao de Labayru. 
habían sublevado ${ }^{42}$. El conflicto entre ambas partes se exacerbó, siendo entregada en 1445 la torre de "Aramayona", según Lope García de Salazar, a don Beltrán de Guevara para que determinase a quien debía corresponderle, a Gómez González de Butrón o a Pedro de Avendaño. La decisión que adoptó Beltrán de Guevara fue favorable al linaje de la Casa de Urquizu ${ }^{43}$. En 1442, Pedro de Avendaño, debió ser convocado a las Juntas de Guernica, sin duda debido a la tirante situación conflictiva entre los partidarios de ambos linajes, pero consiguió de Juan II una carta que le permitió quedarse en sus zonas de influencia ante el temor a ser atacado cuando se dirigiera a dicha localidad ${ }^{44}$.

Otro momento especialmente crítico se produjo en torno a 1443, año en que los Avendaño derrotaron a los Múgica y se afirmaron sobre Aramayo$\mathrm{na}^{45}$, muriendo una persona con el mismo nombre y apellido que el señor de Villarreal de Álava, Pedro de Avendaño, si damos crédito a Lope García de

\footnotetext{
${ }^{42}$ DE CÓMO ÇERCO GOMES CONZALES LA CASA DE PEDRO DE AVENDAÑO DE OCHANDIANO E LA TOMO E QUEMO E DERRIBO POR EL SUELO

En este año mesmo entro Gomes Gonzales poderosamente en la Villa de Ochandiano, e çerco la torre de Pedro de Avendaño, que era mucho fuerte, estando XV omes en ella, e comvatiola por dies dias, e tomola por pleytesia que saliesen los omes a salvo, ca Pedro de Avendaño no la podia socorrer porque el dicho Gomes Gonzales estava apoderado en la villa todo e poderoso, e quemola e derribola por el suelo, e morieron algunos omes en el dicho combate, e otros muchos feridos, e robó e estragó mucho en toda la Villa.

En este año e tiempo se alçaron Pedro Urtis de Garay, e Juan de Garay, su fijo, e Rodrigo de Urrexola, e Furtuno, su hermano, e todos los otros de Aramayona con la fortalesa e Señorio della, e dieronla a Pedro de Avendaño, e poseyola en toda la vida del dicho Gomes Gonzales, e ovieron mucho pleito ante el Conde de Aro, porque le entregaron la fortalesa, e la tovo grand tiempo para los de librar, e no podiendo ygualarlos, ge la tornó al dicho Pedro de Avendaño". Véase Lope GARCíA DE SALAZAR, Las Bienandanzas e Fortunas, vol. IV., p. 208.

43 “Lunes, veinte días de desienbre, año de mil CCCC XLV (1445), partió Gomes Gonçales de Butrón para Aramayona con cuatrocientos omes e entró en Aramayona con ochocientos omes de Butrón e de Música e de Vergara, e estudo ende en tres semanas. E recudió Pedro de Avendaño e juntó mucha gente, e de los que iban en acorro de Pedro, los de Loyola mataron trese omes de don Ladrón de Balda, e pusieron la torre de Aramayona en poder de Veltrán de Guebara por pleitesía que la diesse a quien debía, e la dio después al dicho Pedro". Sabino AGUIRRE GANDARIAS, Las dos primeras crónicas de Vizcaya, p. 159.

${ }^{44}$ Micaela PORTILlA, Torres y casas fuertes en Álava, Vitoria, 1978, p. 1042.

45 “DE LA PELEA QUE OVIERON LOS ESCUDEROS DE MUGICA CON LOS ESCUDEROS DE ARRATIA E DE LOS FECHOS DELLA

En el año del Señor de U CCCCXLIII (1443) años, pelearon los de Mugica, e los de Villela e de Menaca e con escuderos de Arratia, açerca de Mungia, e fueron vençidos los de Mugica, e dexaron muchas armas e Ropas, e Recogieronse a su comarca, levando omes feridos, pero no morieron ningunos omes, ca los de Mugica eran menos, e pusieronse a fuyda a buen tiempo. En este año mesmo levantó Pedro de Avendaño todos sus parientes, e quemó las casas fuertes de Avadiano e de Ochandiano, que eran de Gomes Gonzales, no estando omes en ellas, e entró en Aramayona, e quemó XX casas llanas, e fiso mucho Robo en la tierra, e fue con el Ochoa Sanches de Ginea, prestamero por Mendoça, e mataron a Pedro de Avendaño çinco omes a la salida de la tierra. Por esta causa perdió Gomes Gonzales de Butrón a este Ochoa Sanches de Ginea, çercandolo en la casa de Çubileta, e le fiso pagar muchos dineros por aquella quema que el fue en faser". Lope GARCía DE SALAZAR, Las Bienandanzas e Fortunas, vol. IV, p. 202.
} 
Salazar. Este mismo cronista, ese mismo año, alude al asesinato de otro Pedro de Avendaño, del que se dice es hermano bastardo de Pedro de Avendaño ${ }^{46}$. Las crónicas de Lope García de Salazar continúan en fechas sucesivas refiriéndose a Pedro de Avendaño, que está combatiendo a los linajes Butrón y Múgica, así como dominando sobre Aramayona, comarca no recuperada por los Múgica hasta $1450^{47}$. En estos encontronazos Goméz González de Butrón quemó la casa torre que Pedro de Avendaño poseía en la villa de Ochandiano. De otro lado, los seguidores de los Avendaño y Villela incendiaron la casa torre que Gómez González tenía en Zaballa y atacaron desde la villa de Munguía con una lombarda, propiedad de Pedro de Avendaño, la casa de Bertíquiz.

Vitoria tuvo un evidente recelo a mediados del siglo XV hacia Pedro de Avendaño y el resto de los dueños de señoríos dominicales o jurisdiccionales situados en Álava. En 1444, Juan II, ordenó al Conde de Haro, Fernando de Velasco, al Conde de Treviño, a Diego Gómez Manrique, a Pedro de Sarmiento, a Pedro López de Ayala, a Pedro Vélez de Guevara, a Pedro de Avendaño, a Iñigo de Estúñiga y a Pedro Manrique que no se entrometieran en el embargo de las rentas reales en la zona.

De otro lado es necesario destacar que Pedro de Avendaño, enredado en las luchas banderizas vizcaínas con los Butrón-Múgica, deseosos estos últimos de recuperar el señorío de Aramayona, fue uno de los causantes de la quema de Mondragón en 1448, juntamente con Pedro Vélez de Guevara, señor de Oñate ${ }^{48}$. A corto y medio plazo las consecuencias de tan trágico

\footnotetext{
${ }^{46}$ Lope GARCía DE SALAZAR, Las Bienandanzas e Fortunas, vol. IV, pp. 204-205.

${ }^{47}$ Aproximadamente entre 1437 y 1447 se produjeron diferentes choques armados o agresiones incontroladas entre los componentes del linaje Avendaño y los linajes de Butrón y Múgica en Larrabezúa, en la comarca de Munguía, en Zamudio, en Ochandiano, en Aramayona, en Guernica y en Bermeo.

48 "DE CÓMO LOS DE GElAPA, E GAMBOYNOS, E DE AVENDAÑO, QUEMARON LA VILLA DE MONTE ARAGON, E MATARON A GOMES GONZALES E OTROS MUCHOS, E DE LA CAUSA DELLO, E COMO MORIO EL DICHO GOMES GONZALES.

En este año del Señor de UCCCCXLVIII (1448) años, pelearon los vandos en la villa de Monte Aragon e los de Guraya enbiaron por Gomes Gonzales de Butron, e el fue con todos quantos pudo aver, e con esfuerço de los linajes de Ones, entró en la dicha villa de Monte Aragón con mucha gente por deseo de cobrar por allí Aramayona, e venieron sobre el don Pedro Veles de Guebara, e Pedro de Avendaño e Martin Roys de Arteaga, e entrados en la villa pelearon mucho fuerte, e morieron muchos omes de cada parte, e dende a dos dias venieron Martin Roys de Ganboa, e los de Çaraus, e de Valda e de Yraeta, e todo el poder de los Gamboanos, e don Pedro Velas de Guebara, que no era entrado, e veyendo que no lo podian tomar, por armas, pegaron fuego a la villa, e salieron fuera a esperarlo, quando saliese, e como el vio aquello mandó a los de Unçueta e que los esperasen en unas casas pequeñas de unos ferreros que estavan fuera de la Villa, estavan como arraval, para se barrear alli, ca esperava el acorro de Juan Lopes de Lescano, e de los de Vergara, e de otros, los quales ya eran llegados a dos leguas de alli, e
} 
suceso fueron negativas para los Parientes Mayores solariegos alaveses, guipuzcoanos y vizcaínos. Juan II, en 1449, emitió una carta de perdón favorable a quienes habían sido considerados culpables de la quema de Mondragón, entre los que se hallaban don Pedro Vélez de Guevara y don Pedro de Avendaño. Sin embargo, les exigió el pago de las correspondientes indemnizaciones a los damnificados y ordenó su destierro por tres años a la ciudad de Antequera, conquistada en 1410. En 1451, Butrón, Avendaño y Arteaga entraron en treguas a instancias de las Hermandades vizcaínas ${ }^{49}$. Por supuesto los linajes solariegos vascos se enredaron igualmente en las luchas políticas generales del Reino de Castilla. Los Parientes Mayores de los linajes Avendaño, Olaso, Guevara y Butrón acudieron a la convocatoria de carácter militar efectuada por el Condestable de Castilla, don Álvaro de Luna.

Enrique IV accedió al trono de Castilla en 1454. La situación anterior no se modificó en un grado substancial. En 1457, el rey de Castilla dio una orden de destierro para Pedro de Avendaño y otros caballeros solariegos guipuzcoanos, vizcaínos y alaveses, a consecuencia del papel que había protagonizado poco antes en detrimento de los intereses de las Hermandades de Guipúzcoa. Pedro de Avendaño fue desterrado, de nuevo, en esta ocasión a la villa de Estepona, donde debía permanecer durante 3 años. Por tanto, las relaciones con Enrique IV, en los primeros años de su reinado, tampoco fueron totalmente satisfactorias para el Pariente Mayor de la Casa de Urquizu.

Pese a todo, en 1460, el monarca castellano emitió una carta a su favor destacando la lealtad de Pedro Avendaño a su persona. Enrique IV permitió a sus vasallos que siguieran sirviéndole sin pena alguna, pues había

sopiendo aquella venida, le pegaron el fuego a la Villa, e el quedó en la çaguera a recoger la gente, e apeose de un cavallo, e diolo a Juan Gonzales, su fijo vastardo, que estava ferido mucho mal, en que saliese Martin Roys de Olaso, su yerno, por lo escapar de la muerte, enviole dsir por una su carta con un moço en que saliese en la delantera por donde el e su gentes estava, e que le daria pasada, e como el moço topó con Lope de Ançueta que yba en la delantera, como dicho es, para esperar en aquellas eramenteras e le preguntó por Gomes Gonçales e dixole que que lo quería, e dixole que traya una carta de Martin Roys, su yerno, e dixo, damela que yo só, e tomola e leyonla, e como vio que podía pasar seguro, no curando de esperar allí como lo avian conçertado, fuese su camino por donde Martin Roys le mandava, e pasase con los que yban con le, porque no le destorvó ninguno, cuydando que era Gomes Gonzales, e quando llegó Gomes Gonzales aquellas casas, e no falló a los suyos, viose perdido, e tiró adelante, e topó con los enemigos e mataron alli al dicho Lope Gonzales, e a Juan Gonzales, su fijo, que yba en el cavallo ferido, e Persival, su sobrino, que yba con el, fuese para los de Guebara, e mató al mayordomo de don Pedro Velas, e a otro, antes que lo matasen, e morió allí, e morieron de los de Gomes Gonzales XXV omes alli, e en las primeras peleas de la villa, e morieron de los de Guebara, e Urquiçu, e Arteaga, XIV omes e muchos demasiadamente feridos". Lope GARCÍA DE SALAZAR, Las Bienandanzas e Fortunas, vol. IV, pp. 214-215.

${ }^{49}$ Sabino AguirRe Gandarias, El linaje de Arteaga en la Bizkaia bajo medieval, "Hidalguía", 247 (1994), pp. 799-826 (809). 
vuelto a su fidelidad y le había hecho personalmente pleito homenaje juramentado ${ }^{50}$. De hecho, el monarca notificó a las justicias del rey en el señorío de Vizcaya y en las Provincias de Álava y Guipúzcoa el consentimiento que había otorgado a Pedro de Avendaño ${ }^{51}$ con el fin de que pudiera regresar a sus casas y a dichos territorios. Ahora bien, le exigió previamente su colaboración con las Hermandades, la anulación del desafío establecido por su hijo bastardo homónimo contra el linaje Zárate de la Tierra de Zuya (Álava), la realización del juramento de pleito homenaje en mys manos reales que por syenpre jamas me serviredes lealmente e guardaredes e faredes lo que a my serviçio cumpla como buenos e leales vasallos, el cumplimiento de lo mandatos del rey, el respeto del cuaderno y ordenanzas de las Hermandades, así como la prohibición de fijar ligas y confederaciones con otros caballeros y de desafiar a miembro alguno de las Hermandades ${ }^{52}$.

Pedro de Avendaño, al año siguiente, es decir en 1461, fue uno de los combatientes que participó en el cerco puesto por el ejército castellano a la villa navarra de Viana. Unos años más tarde, en 1468, continuando con su vieja enemistad con los Butrón-Múgica fue uno de los responsables de la derrota sufrida por estos últimos en Elorrio. En estas operaciones militares, Pedro de Avendaño y su hijo Juan de Avendaño, contaron con la inestimable ayuda de los Condes de Haro y de los Condes de Salinas, mientras que los Butrón tuvieron fuerzas militares prestadas por el Marqués de Santillana ${ }^{53}$, así como la ayuda de Juan de Leiba y Lope Hurtado de Salcedo.

En 1469 el Condestable de Castilla don Pedro Fernández de Velasco, según Lope García de Salazar, se dirigió a Vizcaya para acabar con las tropelías supuestamente cometidas por los principales Parientes Mayores vizcaínos, entre los que se citan los Avendaño y Butrón, que tan negativamente repercutían al normal desarrollo del comercio. Fue éste un período particularmente delicado en Castilla. En Vizcaya y en Guipúzcoa algunos habitantes mostraron su oposición al matrimonio de Juana la Beltraneja con

\footnotetext{
${ }^{50}$ Sabino AgUIRRE GANDARIAS, Lope García de Salazar. El primer historiador de Bizkaia (1399-1476), Bilbao, 1994, p. 347.

${ }^{51}$ Orden extensible igualmente a otros Parientes Mayores guipuzcoanos y vizcaínos: Lope García de Salazar, Juan López de Lazcano, Juan Pérez de Loyola, Martín Ruiz de Olaso, Martín Ruiz de Arteaga, Juan de Salcedo, el bachiller Iñigo Martínez de Zaldivia y a Juan López de Gamboa.

${ }^{52}$ Amia ReCALDE RodRíGUEZ; José Luis ORELla UnzúE, Documentación Real a la Provincia de Guipúzcoa. Siglo XV, tomo I, San Sebastián, 1988, número 23.

${ }^{53}$ Lope García DE SAlAZAR, Las Bienandanzas e Fortunas, vol. IV, pp. 121-122.
} 
el duque de Guyena, hermano de Luis XI, rey de Francia. Consideraban esta alianza como muy negativa para sus intereses económicos. Pues bien, en este escenario político enrarecido fueron desterrados del Señorío de Vizcaya los dos Parientes Mayores del linaje Avendaño y Butrón ${ }^{54}$.

En 1470 se produjo el reencuentro y la unión entre los linajes Avendaño y Butrón-Múgica para combatir al Condestable de Castilla, don Pedro Fernández de Velasco, que había sido designado Corregidor de Vizcaya y de quien sospechaban algunos sectores sociales del territorio que pretendía enseñorearse del Señorí ${ }^{55}$. Ambos Parientes Mayores, unidos por don Pedro Manrique, conde de Treviño, pasaron por alto los muertos que ambos bandos habían tenido a causa de los enfrentamientos o peleas acaecidas en 1448 en Mondragón (Gómez González de Butrón, padre de Juan Alonso de Múgica y su hermano Juan González de Butrón) y en 1468, cerca de Bilbao (Juan de Avendaño ${ }^{56}$, hijo primogénito de Pedro de Avendaño ${ }^{57}$ ). De este modo, las fuerzas armadas partidarias de ambos Parientes Mayores, derrotaron a las tropas del Condestable de Castilla. Los contingentes militares de Pedro Fernández de Velasco no pudieron tomar Villarreal de Álava, señorío de los Avendaño y fueron finalmente vencidos en la batalla acontecida en Munguía en $1471^{58}$.

Es interesante destacar que Juan de Avendaño, hijo de Pedro de Avendaño y Manrique de Lara, herido de muerte por una saeta en una pelea el año 1468, fue uno de los caballeros que solicitó en Guernica al corregidor de Vizcaya, Pedro Gómez de Santo Domingo, que se pusieran por escrito los

\footnotetext{
${ }^{54}$ Lope García DE SAlazAR, Las Bienandanzas e Fortunas, vol. IV, pp. 224-225.

${ }^{55}$ Véase E. GARCÍA FERNÁNDEZ, Guerras y enfrentamientos armados: las luchas banderizas vascas, "Los Ejércitos" (Besaide, Vitoria 1994), pp. 59-104 y Arsenio DACOSTA, Los linajes de Bizkaia en la Baja Edad Media: poder, parentesco y conflicto, Bilbao, 2003, pp. 139-143.

${ }^{56}$ DE CÓMO MATARON LOS DE VILVAO A JUAN DE AVENDAÑO EN UNA ESCARAMUÇA EN EL BADO DE YBAYÇAVAL.

Un mes enantes que esta casa se derribase, vino Juan de Avendaño con el solar de su padre de Ybayçaval, a dar favor e ayuda al dicho Diego Sanches de Vasurto, e peleando alli, e escaramuçando cada dia, ovieron una pelea mas arriba de Ybayçaval en el vado, e fue ferido el dicho Juan de Avendaño, fijo eredero de Pedro de Avendaño, de una saeta, estando a cavallo, alçandose en las estribas por tirar la lança, por las verijas, corriendo por el Quexote arriba, e morió dende a tres horas, levandolo en un escudo Arturiaga, e morieron seys omes dambas las partes. Esta muerte fesieron los de Vilvao sin otros ningunos de los solares, e ovo muchos feridos, e partiolos la noche". Lope GARCÍA DE SALAZAR, Las Bienandanzas e Fortunas, vol. IV, p. 122 .

${ }^{57}$ Juan de Avendaño había contraído matrimonio con Beatriz de Ulloa, sobrina de Alfonso de Fonseca, arzobispo de Toledo.

${ }^{58}$ Diego de VALERA, Memorial de diversas hazañas. Edición de J. M. Mata Carriazo, Madrid, 1941, pp. 170 y ss.
} 
fueros de Vizcaya que eran de Albedrio y no estaban escritos. Me refiero al Fuero Viejo de Vizcaya de 1452. Asimismo en 1463 es citado como uno de los diputados elegidos de la tierra llana de el dicho condado que asistió a la Junta de Guernica en la que se

\begin{abstract}
aprobaron por buenos los quadernios de Vizcaya e el Fuero de Vizcaya que agora nuevamente avian recorrido e hordenado e capitulado de la Hermandad, que asi mismo que agora nuevamente havian capitulado e hordenado con todos los buenos fueros, franquezas e libertades que por el dicho sennor rey les fueron mandadas guardar... ${ }^{59}$.
\end{abstract}

Es decir, su padre ya había comenzado a compartir con su hijo algunas de las funciones de liderazgo que incumbían más directamente al Pariente Mayor del linaje. La muerte de Juan de Avendaño alteró las estrategias del linaje de la Casa de Urquizu.

Probablemente la victoria de los Butrón y Avendaño en Munguía sobre los Velasco disparó el interés de estos linajes solariegos por interferir en la dinámica social y política del núcleo urbano más relevante del Señorío de Vizcaya. Los Reyes Católicos, todavía en 1478, emitieron una provisión prohibiendo la entrada en Bilbao a cuatro parientes mayores destacados en el Señorío de Vizcaya: Alfonso de Múgica, Pedro de Avendaño, Juan de Salazar y Fortún García de Arteaga, lo que denota de un lado su poderío y de otro el temor que tenían los vecinos a estos caballeros. Con esta medida se perseguía también la ruptura de las treguas entre los bandos bilbaínos y los linajes solariegos vizcaínos. En 1483, Isabel y Fernando de Castilla, se dirigieron al concejo y oficiales de la villa de Bilbao porque solicitaban las ordenanzas dadas en Vitoria en 1476 para acabar con un sistema de bandos considerado nocivo para la buena marcha de la comunidad de vecinos.

Estas medidas no supusieron el eclipse de las antiguas crispaciones sociales entre los partidarios de los linajes Butrón y Avendaño. De hecho en 1490, Pedro de Avendaño y los aliados del linaje de Urquizu, solicitaron a la Corte el nombramiento de 4 personas de los linajes de Urquizu, Arteaga, Múgica y Butrón para que en unión del Corregidor de Vizcaya examinaran los daños ocasionados en tiempos de los bandos de Oñaz y Gamboa y se compensara a todos lesionados. Tampoco habían desaparecido las viejas

\footnotetext{
${ }^{59} \mathrm{VV}$. AA. Fuentes jurídicas medievales del Señorío de Vizcaya. Cuadernos Legales, Capítulos de la hermandad y Fuero Viejo (1342-1506), San Sebastián, 1986, pp. 77-78.
} 
diferencias existentes entre los gobernantes del concejo de Mondragón y don Pedro de Avendaño Ulloa, a quien reclamaban en 1498 una indemnización por los daños cometidos por su abuelo en la villa en 1448.

La Casa de Urquizu, es decir, Pedro de Avendaño Manrique de Lara tuvo otro frente abierto en la localidad de Vitoria, población que consiguió el título de ciudad en 1431. Los Avendaño fueron propietarios en Vitoria de una casa torre ubicada junto a la puerta principal de la calle Herrería y adosada a la muralla de la localidad. Por circunstancias que no se pueden explicar documentalmente, por el momento, una torre que pertenecía a la población de Vitoria pasó a convertirse en un espacio más de la vivienda de un caballero solariego ${ }^{60}$. Juan Hurtado de Mendoza, prestamero mayor del Señorío de Vizcaya y Pedro de Avendaño litigaron por la propiedad de la casa torre a mediados del siglo XV. Ambos alegaban tener derechos a su titularidad. En 1448, ambos Parientes Mayores para frenar el enfrentamiento entre ellos y sus partidarios, decidieron que dicha casa torre y el solar adyacente quedara bajo el arbitraje de doña María de Mendoza, mientras se resolvía el contencioso ${ }^{61}$.

Los vecinos de Vitoria, en este intervalo, hicieron lo posible para que se mantuvieran intactos sus derechos a utilizar la torre con veladores y guardas en caso de que fuera necesario para defender la ciudad. Doña María de Mendoza les reclamó a cambio el pago de una serie de emolumentos para el alcaide que tenía secuestrada la casa torre en nombre de ella. El concejo de Vitoria trataba de no hacer ninguna dejación de derechos a favor de unos señores solariegos de la entidad de los linajes Avendaño y Mendoza, lo que podría comprometer la autoridad de los gobernantes de la ciudad. Finalmente, Diego Martínez de Álava, que logró adquirirla en propiedad, recordaba en 1485 al alcalde, regidores y diputados del concejo de Vitoria el bien que había hecho a la ciudad al haberla comprado, con el claro propósito de que le dejaran abrir una ventana y realizar algunas reparaciones. La solicitud fue contemplada de forma favorable por el concejo de la ciudad. comprado

El todavía escribano, Diego Martínez de Álava, afirmaba que había

${ }^{60}$ Archivo Municipal de Vitoria, 15/19/1 (1410). En un documento fechado en 1410 se certifica que Juan Pérez de Gámiz, ferrero y un hijo suyo habitaban en la torre de la calle Herrería, propiedad del concejo de Vitoria, la cual por otra parte no debía estar en muy buenas condiciones de habitación, pues tenía goteras entre otras averías.

${ }^{61}$ Archivo Municipal de Vitoria, 15/19/5 (1448). 
del sennor Pedro de Avendanno la torre de la ferreria lo qual commo ellos sabian hera en serviçio desta dicha çibdad e el queria fraguar la dicha torre e avia nesçesario asy commo otros vesinos desta dicha çibdad de faser una ventana e una lunbrera e otros reparos en ellas que les pedia e suplicava le diesen liçençia para ello e luego los suso dichos mandaron al dicho Diego Martines que pueda faser la dicha ventana de manera que non sea mas baxa que las otras e con el menor perjuisio que se pueda faser en el dicho muro tornando la piedra al concejo ${ }^{62}$.

Desde luego, la compra de dicha casa torre limitaba la influencia del Pariente Mayor de los Avendaño en los asuntos de la ciudad, pues le dejaba sin una casa, posible punto de partida de otro tipo de derechos e influencias ciudadanas. Pero, sobre todo, se aprecia en el contenido de la demanda de Diego Martínez de Álava un deseo explícito de las elites vitorianas de que el Pariente Mayor del linaje Avendaño no poseyera una casa en la ciudad, lo que se explica perfectamente en ese contexto de pugna de intereses entre el concejo de Vitoria y la nobleza solariega. La nobleza castellana y los caballeros solariegos, por su lado, intentaron influir en Vitoria aprovechando los intersticios abiertos dejados por las desavenencias existentes entre los dos bandos de la ciudad, el de Ayala y el "de la Calleja"63. A los Avendaño se les dibuja juntamente con los Velasco, Guevara y Sarmiento aupando al bando vitoriano "de la Calleja", mientras que el bando vitoriano de Ayala contaría con el sostén de la Casa de Ayala, los Mendoza y los Butrón.

Los años en que Pedro de Avendaño Manrique de Lara estuvo a la cabeza de la Casa de Urquizu fueron especialmente conflictivos. Esta época se corresponde con una etapa histórica compleja en la que se sucedieron tres monarcas en la Corona de Castilla: Juan II, Enrique IV e Isabel la Católica.

\footnotetext{
${ }^{62}$ Archivo Municipal de Vitoria, Libro de Acuerdos número 2, folio $187 \mathrm{v}$.

${ }^{63} \mathrm{~A}$ fines del siglo XV así lo describía un vecino de Vitoria, Pedro Fernández de Zuazo, actuando como testigo en un pleito: "...los sennores de Ayala tenían sus palaçios en la Villa de Suso y este testigo los vio que se quemaron al tienpo de los vandos y eso mismo dixo este testigo que al dicho tienpo de los vandos que avia en esta çibdad que sabe e vio que el apellido de un vando se dezia de Ayala y el otro Calleja e que del bando de Ayala heran los sennores de Ayala y los sennores de Mendoça e Gomez de Butron y otros cavalleros sennores de vasallos de la dicha probinçia y el sennor de Arraya y el sennor de Lazcano e del apellido e vando de Calleja heran el Condestable de Castilla e el Conde de Oñate e el Conde de Sallinas e Martin Ruiz de Avendaño y otros sennores que tenian vasallos e tierra en la dicha probinçia e que oyo desir de su padre e de sus mas ançianos por cosa notoria que esta çibdad se despoblo a causa de los dichos vandos por muchas quemas e muertes que por ellos obo porque hera mucho mas poblada". Véase Ernesto GARCÍA FERNÁNDEZ, Gobernar la ciudad en la Edad Media: oligarquías y elites urbanas en el País Vasco, Bilbao, 2004, p. 222.
} 


\section{De Pedro de Avendaño Ulloa a Martín Ruiz de Avendaño López de Gamboa, contrapunto político del Conde de Salvatierra}

Finalmente Pedro de Avendaño Manrique de Lara murió en 1490, siendo sustituido en el señorío por su nieto Pedro de Avendaño Ulloa, a quien el rey le concedió ese mismo año el patronazgo de los monasterios de Olabarrieta y de Santa María de Alboniga, así como los oficios de merino de Arratia y Zornoza, que había regentado previamente su abuelo. No se tiene noticias de que Pedro de Avendaño y Ulloa participara en la armada de la archiduquesa con destino a Flandes organizada en $1494^{64}$, falleciendo cinco años después, en 1499.

Su sobrino Martín de Gamboa y Avendaño estuvo comprometido en las luchas de los ejércitos castellanos contra los musulmanes granadinos ${ }^{65}$. Éste último acabaría heredando el mayorazgo de la Casa de Urquizu, tras la muerte de Francisca de Avendaño Velasco, única hija de Pedro de Avendaño Ulloa. De este modo, el nuevo señor de Villarreal de Álava fue igualmente conocido con el nombre de Martín Ruiz de Avendaño y Gamboa, que unió en su persona las casas de Olaso y Urquizu. Hubo un proyecto de boda con Isabel Sarmiento, tía del conde de Salinas, Diego Gómez Sarmiento, que todavía no tenía la mayoría de edad en $1504^{66}$.

Pero, Martín Ruiz de Avendaño se casó con Isabel de Velasco, hija de Bernardino de Velasco, condestable de Castilla y tutor de Francisca de Avendaño Velasco. Existieron razones de peso que incidieron en el cambio de opinión de Martín Ruiz de Avendaño. Éste rompió los contratos matrimoniales anteriores, probablemente porque creyó que era la mejor forma de asegurar el señorío sobre Villarreal de Álava y sus aldeas. En cualquier casó este personaje contó con una fuerte oposición en Villarreal de Álava y en el

${ }^{64}$ Miguel Ángel Ladero QuesadA, La 'Armada de Vizcaya' (1492-1493): Nuevos datos documentales, "En la España Medieval”, 24 (2001), pp. 365-394. Por el contrario, sí participaron en esta travesía marítima otros parientes suyos. En concreto Juan de Avendaño, con gentes de Durango y Arratia, así como San Juan de Avendaño con soldados de Villaro y Uribe. Véase Miguel Ángel LADERO QUESADA, La armada de Flandes. Un episodio en la política naval de los Reyes Católicos (1496-1497). Madrid, 2003, pp. 123-128.

${ }^{65}$ De hecho acudió a la guerra de Granada en representación de las obligaciones que tenía contraídas la villa vizcaína de Villaro. C. HidALGO DE CISNEROS AMESTOY; E. LARGACHA RUBIO; A. LORENTE RUIGÓMEZ; A. MARTÍNEZ LAHIDALGA, Colección Documental del Archivo Municipal de Durango, tomo II, San Sebastián, 1989, n 73 , p. 389.

${ }^{66}$ A.R.Ch.Valladolid. Reales Ejecutorias, c. 191/16. Isabel de Sarmiento, debido a que Martín Ruiz de Avendaño no la acabó aceptando por su mujer, aunque este último ya había recibido la dote, decidió meterse en un convento. 
valle de Zuya, zona esta última donde mató a uno de los líderes que más se le resistieron y ordenó ahorcar al menos a otros $\operatorname{dos}^{67}$. Villarreal de Álava no logró escapar al yugo señorial de los Avendaño. Martín Ruiz de Avendaño es reconocido por la historiografía sobre todo por haber contribuido de manera notable a la derrota del Conde de Salvatierra, don Pedro López de Ayala, máximo exponente en estos territorios de la Junta comunera de Tordesillas.

Martín Ruiz de Avendaño fue sucedido en el mayorazgo por su hijo don Prudencio de Avendaño que entroncó con los Beaumont navarros, señores del palacio de Arazuri. Un hermano de Prudencio, llamado Martín Ruiz de Avendaño, como su padre, vivió la aventura americana, desplazándose a Perú con doce criados suyos ${ }^{68}$. A mediados del siglo XVI los descendientes de Martín Ruiz de Avendaño y Gamboa llegaron a desempeñar una de las cinco alcaldías de fuero del Señorío de Vizcaya, circunstancia que no se produjo en los siglos XIV y XV ${ }^{69}$. Asimismo monopolizaron el prebostazgo de la villa de Guerricaiz, los oficios de merino de Busturia, Arratia, Zornoza y Uribe y por supuesto continuaron detentando el oficio de Ballestero Mayor del rey de Castilla.

\section{EPÍLOGO CONCLUSIVO}

Creo que el estudio prosopográfico y social del linaje Avendaño ha permitido demostrar que la privanza o el servicio a los Señores de Vizcaya y a los monarcas castellanos aupó a los titulares de la Casa solariega de Urquizu a las cumbres del poder en la Corona de Castilla, aunque sobre todo sobresalieron en el Señorío de Vizcaya y en el norte de la Provincia de Álava. Sólo las uniones matrimoniales con los señores del solar de Olaso dispararon su influencia sobre algunas comarcas guipuzcoanas. Igualmente Bilbao y Vitoria fueron centros urbanos por los que se interesaron los Parientes Mayores del linaje. El entramado social generado en torno a los Parientes

${ }^{67}$ J. L. VIDAURRÁZAGA; J.L. INCHAUSTI, Nobiliario alavés de Fray Juan de Victoria. Siglo XVI, Bilbao, 1975, p. 365.

${ }^{68}$ Archivo General de Indias. Indiferente, 1964, L. 11. F. 2,15 v. Licencia de pasajeros a Martín de Avendaño y Gamboa y a doce criados para que le dejen pasar a Perú. Valladolid 22-051549 y Santo Domingo 1121, L. 1, I, 178 v. Monzón, 25-10-1533. Don Martín de Avendaño "idem para don Martin de Avendaño y Ganboa y doze criados para el Perú".

${ }^{69}$ Por el contrario a fines del siglo XV un pariente del linaje Avendaño, también llamado Pedro de Avendaño, vecino de Munguía y Pariente Mayor del solar de Villela, había conseguido ser uno de los 5 alcaldes de Fuero de Vizcaya. 
Mayores del linaje se sustentó al mismo tiempo en su poderío económico en estos territorios y en sus preeminencias señoriales. Éstas incluyen su patronazgo sobre numerosas iglesias parroquiales, algunas de las cuales, sobre todo desde principios del siglo XVI, estaban ubicadas en núcleos urbanos importantes (Elgóibar, Éibar, Plasencia y Elorrio). El conjunto de todas estas variables constituyeron la base de las diversas estrategias seguidas por los Parientes Mayores de la Casa de Urquizu.

Las estrechas relaciones personales y de parentesco de los señores de la villa de Villarreal de Álava con los señores de la Casa de Olaso (Elgóibar) propulsaron al linaje Avendaño a la cúspide del bando Gamboíno en Vizcaya. Ya las genealogías bajomedievales entroncaban desde comienzos del siglo XIII a los Guevara, Salcedo, Avendaño, Ayala y Gamboa, linajes que significaron el núcleo del bando gamboíno enfrentado al denominado bando oñacino. Estas luchas sociales y políticas, sin embargo, no fueron tan uniformes ni se encuadraron siempre en el marco de los tradicionales bandos gamboíno y oñacino. Sin duda, detrás de estos conflictos se dilucidaban distintas cotas de poder entre los linajes solariegos, los gobernantes de las villas y las Hermandades alavesas, guipuzcoanas y vizcaínas.

El debilitamiento de las Luchas de Bandos en el País Vasco fue paralelo durante el siglo $\mathrm{XV}$ al surgimiento de una fuerte protesta antiseñorial de sus vasallos de la villa de Villarreal y sus aldeas. La crispación generada fue muy intensa desde mediados de la década de los 80 del siglo XV, siendo todavía señor de la villa don Pedro de Avendaño Manrique de Lara. Los conflictos con los vecinos de Villarreal de Álava no sólo no cesaron, sino que se reavivaron de nuevo a la muerte de Francisca de Avendaño, pese a la sentencia favorable a los intereses de la villa y las aldeas emitida en 1487 por los tribunales de justicia ${ }^{70}$.

Quiero acabar estas líneas señalando que los Parientes Mayores de la Casa de Urquizu, vizcaínos de origen alavés, defendieron con ahínco los Fueros de Vizcaya al mismo tiempo que fueron, con alguna excepción que otra, fieles vasallos de los reyes castellanos. El máximo exponente de su lealtad fue su apoyo al emperador Carlos V y su oposición a la Junta Comunera de Tordesillas, representada en el País Vasco por el noble caballero

\footnotetext{
${ }^{70}$ Véase Ernesto GARCÍA FERNÁNDEZ, Fortuna y poder de un linaje medieval: los Avendaño, señores de Villarreal de Álava, en Homenaje a Micaela Portilla Vitoria. Jornadas Congresuales in Memoriam, 21, 22, 23, 24 de febrero, Vitoria (2007). En prensa.
} 
don Pedro López de Ayala, cuyas tropas sucumbieron en 1521, cerca de Vitoria, a las comandadas por don Martín Ruiz de Avendaño.

El arraigo socio-señorial del linaje Avendaño en el actual País Vasco fue considerable, pero no tuvo la fortuna o la capacidad de conseguir de los reyes castellanos un título nobiliario de prestigio, al contrario de los Guevara, Ayala, Manrique y Sarmiento condes de Oñate, Salvatierra de Álava, Treviño y de Salinas, respectivamente. El protagonismo político del linaje Avendaño se dejó notar con fuerza sobre todo en el señorío de Vizcaya durante los siglos XIV y XV. En las Juntas Generales de Guernica tuvieron un puesto destacado entre los linajes solariegos de la Tierra Llana de Vizcaya. La especialización del linaje en el oficio de la guerra fue un puntal más de su influencia en la Corte y en estos territorios. Conviene recordar que en 1521 las tropas capitaneadas por Martín Ruiz de Avendaño no sólo sirvieron de contrapeso a los partidarios de la Junta comunera de Tordesillas, sino que derrotaron en las proximidades de Vitoria a los ejércitos dirigidos por Pedro López de Ayala "el comunero".

Colofón de todo ello fue la posterior asistencia de don Martín Ruiz de Avendaño a las Cortes Generales de Castilla. En las Cortes de Valladolid llevadas a cabo en octubre de 1538 estuvieron presentes entre los Grandes del Reino, de un lado don Juan Alonso de Múgica, señor de las Casas de Múgica y Butrón, y de otro Martín Ruiz de Avendaño. Asimismo en las Cortes de Toledo de ese mismo año asistió Martín Ruiz de Avendaño para votar una comisión que estudiara el medio de ayudar financieramente al emperador Carlos V. ¡Qué mejor forma de destacar el poder de la Casa de Urquizu!.

Fecha de recepción del artículo: mayo 2007.

Fecha de aceptación y versión final: julio 2007. 


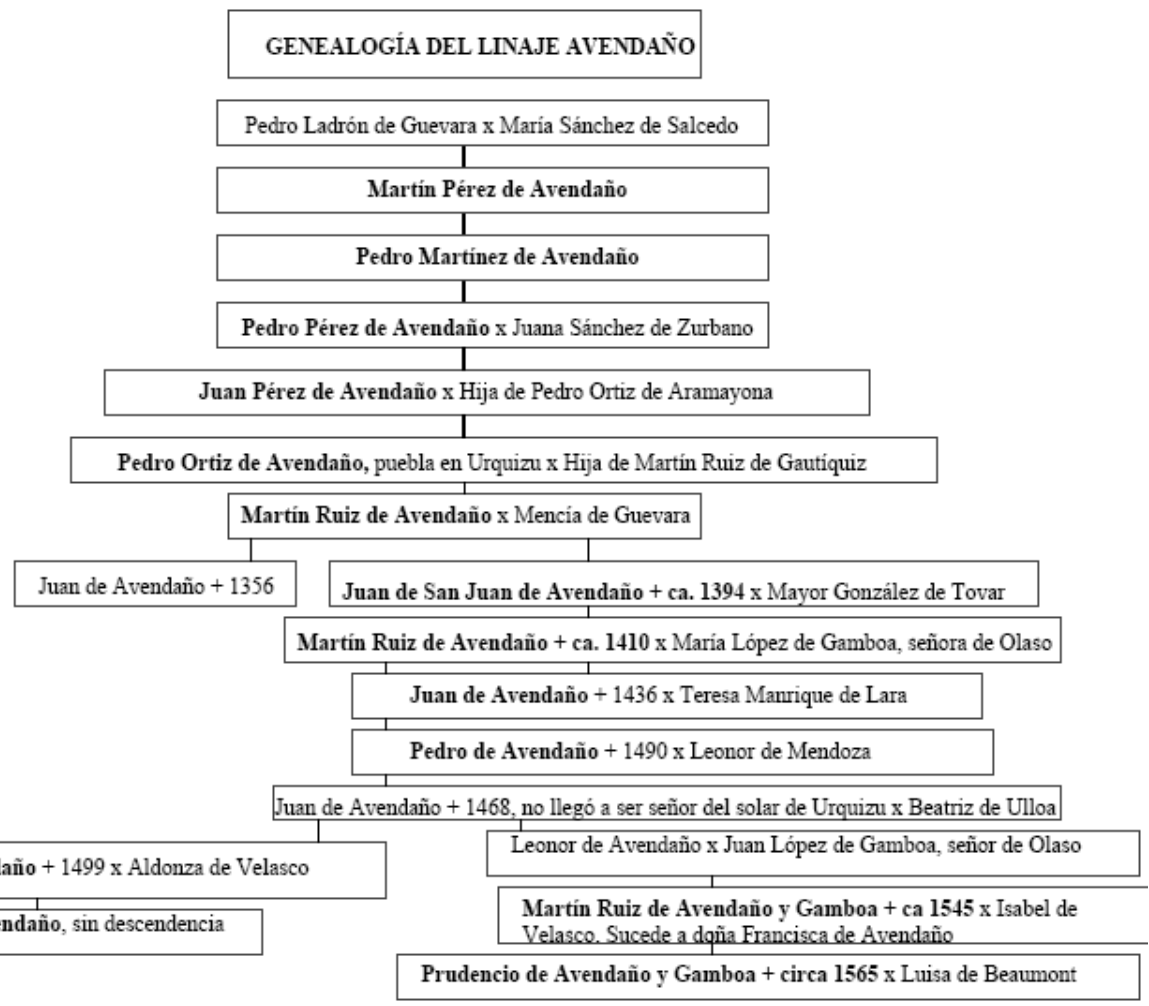


MAPA 1.

El linaje Avendaño: del Solar de Urquizu a Bilbao, Villarreal y Vitoria (siglos XIV-XV)

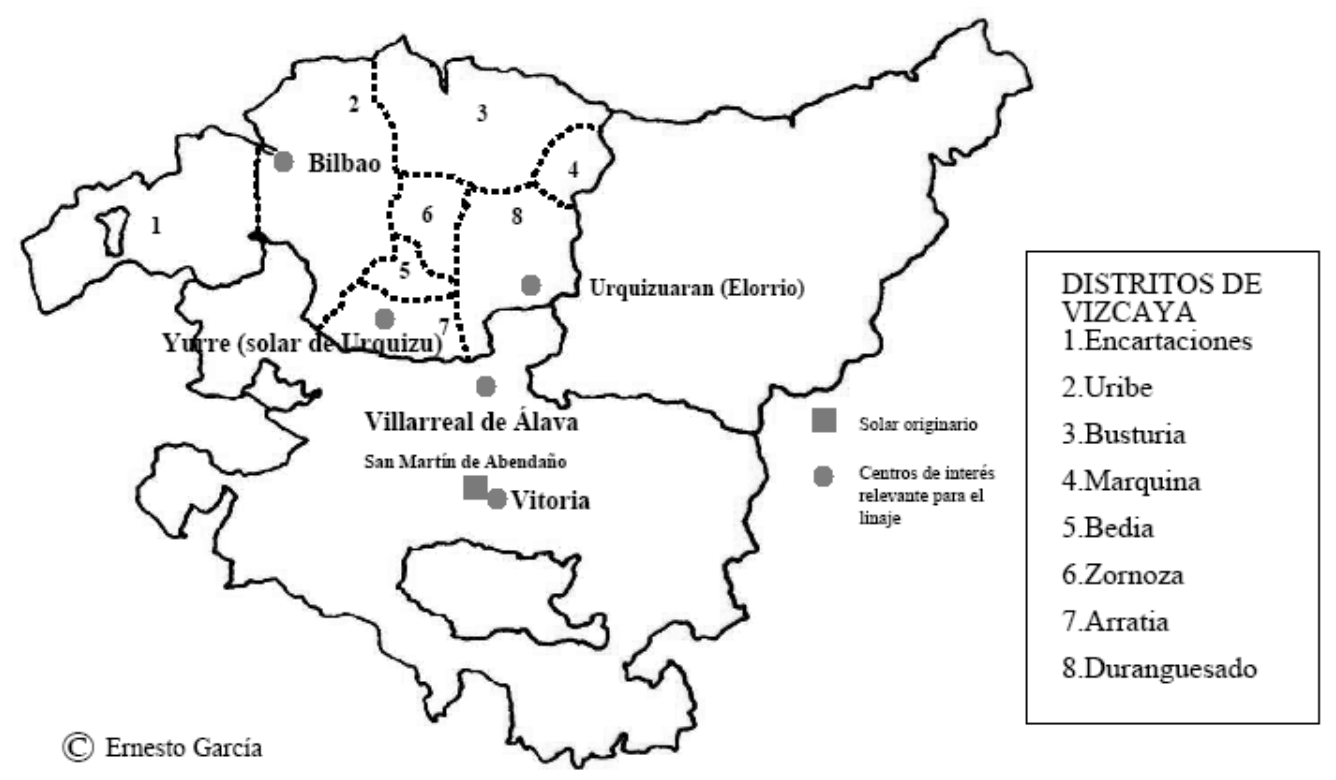


MAPA 2: Monasterios e iglesias de patronazgo del linaje Avendaño de Urquizu (s. XIV-XVI)

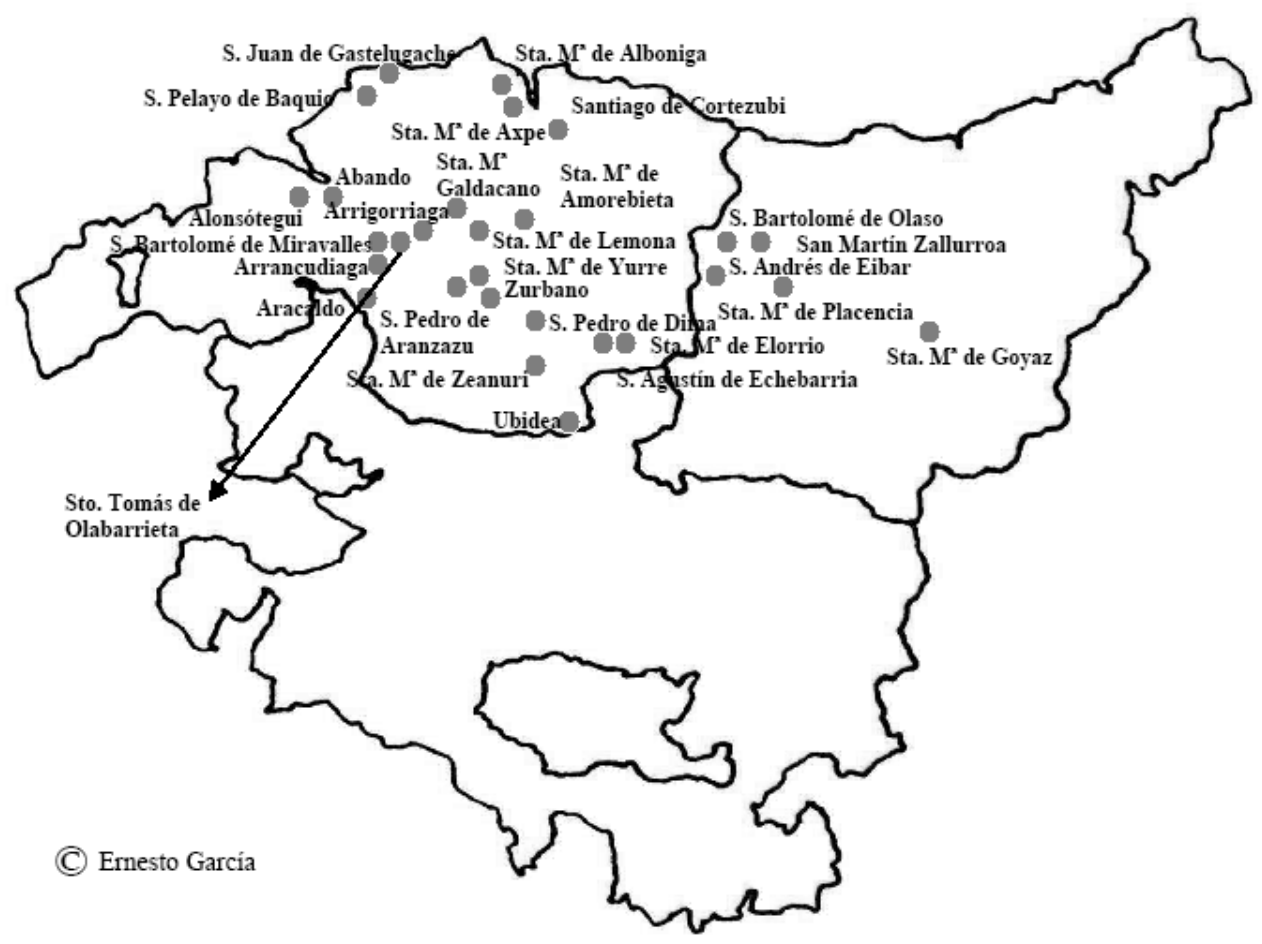

